\title{
Expedition 327 summary ${ }^{1}$
}

\author{
Expedition 327 Scientists $^{2}$
}

\section{Chapter contents}

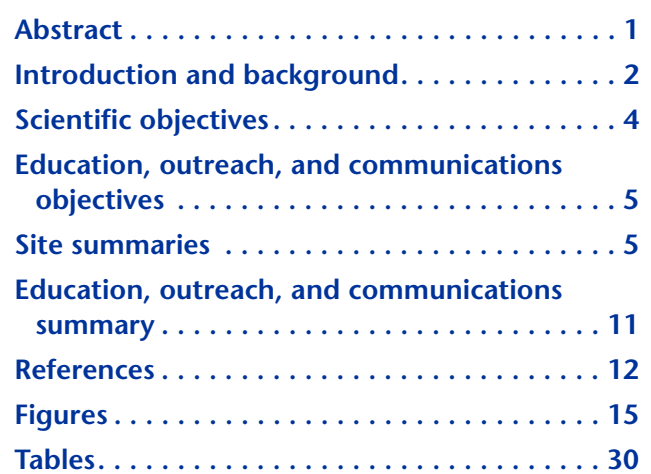

${ }^{1}$ Expedition 327 Scientists, 2011. Expedition 327 summary. In Fisher, A.T., Tsuji, T., Petronotis, K., and the Expedition 327 Scientists, Proc. IODP, 327: Tokyo (Integrated Ocean Drilling Program Management International, Inc.). doi:10.2204/iodp.proc.327.101.2011

'Expedition 327 Scientists' addresses.

\section{Abstract}

Integrated Ocean Drilling Program (IODP) Expedition 327 and related experiments focus on understanding fluid-rock interactions in young upper ocean crust on the eastern flank of the Juan de Fuca Ridge, delineating the magnitude and distribution of hydrologic properties; the extent to which crustal compartments are connected or isolated (laterally and with depth); the rates and spatial extent of ridge-flank fluid circulation; and links between ridge-flank circulation, crustal alteration, and geomicrobial processes. Expedition 327 built on the achievements of Ocean Drilling Program (ODP) Leg 168, IODP Expedition 301, and subsequent submersible and remotely operated vehicle (ROV) expeditions. During earlier drilling expeditions, subseafloor borehole observatories ("CORKs") were installed in basement holes to allow borehole conditions to recover to a more natural state after the dissipation of disturbances caused by drilling, casing, and other operations; to provide a long-term monitoring and sampling presence for determining fluid pressure, temperature, composition, and microbiology; and to facilitate the completion of active experiments to resolve crustal hydrogeologic conditions and processes.

During Expedition 327, two basement holes were cored and drilled at Site U1362. Hole U1362A was cored and drilled to 528 meters below seafloor (mbsf) (292 meters subbasement [msb]), geophysically logged and hydrologically tested, and instrumented with a multilevel CORK observatory. Hole U1362B was drilled to $359 \mathrm{mbsf}$ (117 msb), tested with a $24 \mathrm{~h}$ pumping and tracer injection experiment, and instrumented with a single-level CORK observatory. Both CORK observatories include pressure and temperature monitoring and downhole fluid and microbiology sampling and experiments. Wellhead samplers will be added and a longterm cross-hole test will be initiated during a postdrilling ROV expedition scheduled for summer 2011. In addition, part of an instrument string deployed in Hole U1301B during Expedition 301 was recovered during Expedition 327, and a replacement string of thermal sensors was installed. Finally, a program of shallow sediment coring was completed adjacent to Grizzly Bare outcrop, a location where regional hydrothermal recharge occurs. Thermal measurements and analyses of pore fluid and microbiological samples from a series of holes aligned radially from the outcrop edge will elucidate rates of fluid transport and evolution during the initial stages of ridge-flank hydrothermal circulation. 


\section{Introduction and background}

Fluid flow within the volcanic oceanic crust influences the thermal and chemical state and evolution of oceanic lithosphere and lithospheric fluids; subseafloor microbial ecosystems; diagenetic, seismic, and magmatic activity along plate-boundary faults; creation of ore and hydrate deposits both on and below the seafloor; and exchange of fluids and solutes across continental margins (e.g., Alt, 1995; Huber et al., 2006; Parsons and Sclater, 1977; Peacock and Wang, 1999). The global hydrothermal fluid mass flux through the upper oceanic crust rivals the global riverine fluid flux to the ocean and effectively passes the volume of the oceans through the crust once every $10^{5}-10^{6}$ y (Elderfield and Schultz, 1996; Johnson and Pruis, 2003; Mottl, 2003; Wheat et al., 2003a). Most of this flow occurs at relatively low temperatures, far from volcanically active seafloor-spreading centers where new ocean floor is created. This "ridgeflank" circulation can be influenced by off-axis volcanic or tectonic activity but is driven mainly by the transport of lithospheric heat from below the crust. Although the average maximum age at which measurable heat is lost advectively from oceanic lithosphere is $65 \mathrm{Ma}$ (Parsons and Sclater, 1977), many sites remain hydrologically active for tens of millions of years beyond this age, with circulation largely confined to basement rocks that redistribute heat below thick sediments (Fisher and Von Herzen, 2005; Von Herzen, 2004).

Despite the importance of fluid-rock interactions in the crust, little is known about the magnitude and distribution of critical hydrologic properties; the extent to which crustal compartments are well connected or isolated (laterally and with depth); the rates and spatial extent of ridge-flank fluid circulation; or the links between ridge-flank circulation, crustal alteration, and geomicrobial processes. Integrated Ocean Drilling Program (IODP) Expedition 327 is part of a long-term experimental program that began nearly two decades ago and has included multiple survey, drilling, submersible, and remotely operated vehicle (ROV) expeditions; observatory and laboratory testing, sampling, and monitoring; and modeling of coupled fluid-thermal-chemical-microbial processes. Expedition 327 builds on the technical and scientific achievements and lessons learned during Ocean Drilling Program (ODP) Leg 168 (Davis, Fisher, Firth, et al., 1997), which focused on hydrothermal processes within uppermost basement rocks and sediments along an age transect (Fig. F1), and IODP Expedition 301 (Fisher, Urabe, Klaus, and the Expedition 301 Scientists, 2005), which penetrated deeper into the crust at the eastern end of the Leg 168 transect (Fig. F2). During both expeditions, subseafloor borehole observatories ("CORKs") were installed in basement holes to allow borehole conditions to recover to a more natural state after the dissipation of disturbances caused by drilling, casing, and other operations; to provide a long-term monitoring and sampling presence for determining fluid pressure, temperature, composition, and microbiology; and to facilitate the completion of active experiments to resolve crustal hydrogeologic conditions and processes (Fisher et al., 2005). During subsequent ROV and submersible expeditions, data were downloaded from the Leg 168 and Expedition 301 CORKs, and batteries, data loggers, and sampling systems at the seafloor and downhole were replaced.

The primary goals of Expedition 327 were to

1. Drill two new basement holes, core and wireline log one of these holes across a depth range of 100-360 meters subbasement (msb), conduct a $24 \mathrm{~h}$ pumping and tracer injection test, and install a multilevel CORK in each of the new holes;

2. Recover an existing CORK installed in a shallow basement hole during Leg 168, deepen the hole by $\sim 40 \mathrm{~m}$, and install a new multilevel CORK with instrumentation; and

3. Recover and replace an instrument string deployed in one of the Expedition 301 CORKs.

Secondary objectives included sampling and analyzing sediment cores to map patterns of ridge-flank hydrothermal circulation in underlying basement rocks.

\section{Geological setting and earlier work}

Many studies have summarized geology, geophysics, and basement-fluid chemistry and hydrogeology within young seafloor on the eastern flank of the Endeavour segment of the Juan de Fuca Ridge (e.g., Davis et al., 1992; Elderfield et al., 1999; Fisher et al., 2003; Hutnak et al., 2006; Mottl et al., 1998; Stein and Fisher, 2003; Wheat and Mottl, 1994; Wheat et al., 2000, 2003b, 2004). Topographic relief associated with the Juan de Fuca Ridge axis and abyssal hill bathymetry on the ridge flank has helped trap turbidites flowing west from the continental margin (Fig. F1), which has resulted in burial of young oceanic basement rocks under thick sediments. Sediment cover is regionally thicker and more continuous to the east, but there are seamounts and smaller basement outcrops up to $100 \mathrm{~km}$ east of the spreading center, including areas north and south of the Expedition 327 work area. Regional basement relief is dominated by linear ridges and troughs (Fig. F3A) oriented subparallel to the spreading center and produced mainly by faulting, variations in magmatic supply at the ridge, and off-axis volcanism. Low-permeability sediment limits advective heat loss across 
most of the ridge flank, resulting in strong thermal, chemical, and alteration gradients in basement.

During Leg 168, a transect of eight sites was drilled across 0.9-3.6 Ma seafloor; sediment, rock, and fluid samples were collected; thermal, geochemical, and hydrogeologic conditions in basement were determined; and a series of CORKs was installed in the upper crust (Davis, Fisher, Firth, et al., 1997). Two of the Leg 168 observatories were placed in 3.5-3.6 Ma seafloor in Holes 1026B and 1027C, near the eastern end of the drilling transect (Figs. F2, F3A). Expedition 301 returned to this area and drilled deeper into basement; sampled additional sediment, basalt, and microbiological materials; replaced the borehole observatory in Hole 1026B; and established two additional CORK observatories at Site U1301 for use in long-term, three-dimensional hydrogeologic experiments (Fisher, Urabe, Klaus, and the Expedition 301 Scientists, 2005).

Before Leg 168 there was a largely two-dimensional view of the dominant fluid-circulation pathways across the eastern flank of the Juan de Fuca Ridge, with recharge occurring mainly across areas of basement exposure close to the ridge (near the western end of the Leg 168 transect) and flowing toward the east. Some results from Leg 168 are nominally consistent with this view, including seafloor heat flow and basement temperatures that increase and basement fluids that are warmer and generally more altered with progression from west to east along the drilling transect (Davis et al., 1999; Elderfield et al., 1999; Stein and Fisher, 2003). However, Leg 168 results and subsequent surveys revealed inconsistencies with this simple model of large-scale hydrogeologic flow. For example, although basement fluids are warmer with increasing distance from the ridge, fluid ${ }^{14} \mathrm{C}$ ages and sulfate data preclude a general flow in basement from west to east, despite being warmer and more altered (Elderfield et al., 1999; Walker et al., 2007). In addition, reexamination of bathymetric data near Sites 1023-1025 shows that basement outcrops to the north and south could allow hydrothermal fluids to recharge and discharge, with flow occurring largely perpendicular to the Leg 168 transect, consistent with results along the eastern transect of boreholes in a south-north direction (Fisher et al., 2003; Hutnak et al., 2006; Wheat et al., 2000). It is also difficult to understand how basement fluids flowing from west to east at the eastern end of the Leg 168 transect might exit the crust where sediment cover is thick and continuous and there are no known outcrops (Davis et al., 1999; Hutnak et al., 2006).
Regional site surveys in preparation for Expedition 301 focused on and near basement outcrops that could be fluid entry and exit points to and from the crust (Fisher et al., 2003; Hutnak et al., 2006; Zühlsdorff et al., 2005). Thermal data suggest a significant component of south-north (ridge parallel, along strike) fluid flow in basement at the eastern end of the Leg 168 transect, an interpretation consistent with geochemical studies (Walker et al., 2007; Wheat et al., 2000). Bathymetric, sediment thickness, and heat flow data near the western end of the Leg 168 transect also are consistent with a significant component of north-south fluid flow in basement (Hutnak et al., 2006). Numerical models were created to simulate single-outcrop and outcrop-to-outcrop hydrothermal circulation between Grizzly Bare and Baby Bare outcrops (separated by $52 \mathrm{~km}$ in the along-strike direction) and to estimate the nature of basement properties that would allow these inferred patterns and rates of fluid circulation (Fig. F4). These studies show that outcrop-to-outcrop hydrothermal circulation can be sustained when basement permeability is $\geq 10^{-12} \mathrm{~m}^{2}$. At lower permeabilities, too much energy is lost during lateral fluid transport for circulation to continue without forcing, given the limited driving pressure difference at the base of recharging and discharging fluid columns (Hutnak et al., 2006). In addition, fluid temperatures in upper basement are highly sensitive to modeled crustal permeability. When crustal permeability is too high $\left(10^{-10}\right.$ to $10^{-9}$ $\mathrm{m}^{2}$ ), as interpreted from analyses of formation responses to tidal and tectonic perturbations, fluid circulation is so rapid that basement is chilled to temperatures far below those measured regionally (modeled values of $20^{\circ}-50^{\circ} \mathrm{C}$ ). A good match is achieved to observed upper basement temperatures of $60^{\circ}-65^{\circ} \mathrm{C}$ when lateral basement permeability is $\sim 10^{-11} \mathrm{~m}^{2}$ (Fig. F4).

Drill string packer experiments in upper basement during Expedition 301 indicate a layered crustal structure with permeabilities of $10^{-12}$ to $10^{-11} \mathrm{~m}^{2}$ (Becker and Fisher, 2008). Additional hydrogeologic analyses completed using the formation pressure response to the long-term flow of cold bottom seawater into basement at Site U1301 in the 13 months after drilling, as observed at Site 1027 (2.4 km away) (Fisher et al., 2008), suggest large-scale permeability at the low end of or below values indicated by shortterm packer testing (Fig. F5). Results from borehole testing during and after Expedition 301 are broadly consistent with the global ensemble of measurements, but (larger scale) cross-hole tests indicate lower crustal permeability than do (smaller scale) 
single-hole tests (Fig. F6). This result was unexpected because larger scale testing tends to give greater effective permeability values in crystalline rocks.

The results from both sets of measurements and the difference between these permeability estimates and others based on modeling and analyses of formation responses to tidal and tectonic perturbations may be reconciled by azimuthal anisotropy in basement hydrogeologic properties (Fig. F5). Azimuthal permeability anisotropy is also consistent with preferential flow in the north-south direction at both ends of the Leg 168 transect, inferred from independent thermal and chemical observations, and with the highly faulted nature of the upper crust in the Expedition 327 field area (Fig. F3A). Experiments conducted during and planned for after Expedition 327 will provide a direct test of permeability anisotropy using a network of sealed borehole observatories.

\section{Seismic studies and site survey data}

Two site surveys were completed in 2000 in support of Expeditions 301 and 327. The ImageFlux survey was completed with the R/V Sonne and included nearly 500 lines of seismic data and extensive hydrosweep coverage (Zühlsdorff et al., 2005; Zühlsdorff and Spiess, 2006). The RetroFlux expedition was completed on the R/V Thomas G. Thompson with a focus on coring and heat flow and limited acquisition of hydrosweep data (Fisher et al., 2003; Hutnak et al., 2006). Finally, a 2002 expedition of the R/V Maurice Ewing collected multichannel seismic (MCS) data mainly across the Juan de Fuca Ridge, with seismic lines positioned to cross Leg 168 and Expedition $301 / 327$ drill sites and additional secondary sites (Carbotte et al., 2008; Nedimovic et al., 2008). Collectively, these data provided clear drilling targets for Expedition 327 (Fig. F3).

Conversions from two-way traveltime between the seafloor and top of basement to sediment thickness were developed by Davis et al. (1999) using drilling results from Leg 168 (Davis, Fisher, Firth, et al., 1997). Shipboard $P$-wave velocity measurements made on recovered sediments were combined to generate an equation for time-depth conversion. This conversion was shifted linearly to force a fit through basement depths determined during drilling, with a resulting sediment velocity range of 1500-1700 m/s. For Expedition 327 the greatest uncertainty in estimating depths for drilling goals from seismic data lay in picking targets where the upper basement surface is sloped and irregular. Experience from Leg 168 and Expedition 301 suggested that these picks have uncertainties of $\pm 5-10 \mathrm{~m}$, which is consistent with our experience during this expedition.

\section{Scientific objectives}

The primary scientific objectives for Expedition 327 comprised work at Sites U1362 (prospectus Sites SR-2A and SR-2B; Fisher et al., 2010), 1027, and U1301. Secondary scientific objectives were achieved at Site U1363 (prospectus Sites GRB-1A, GRB-2A, and GRB-3A), adjacent to Grizzly Bare outcrop.

\section{Site U1362}

We intended to drill and case Hole U1362A (prospectus Site SR-2A), the deepest of the two new holes drilled during Expedition 327, through the sedimentary section and uppermost $100 \mathrm{~m}$ of basement, with coring planned only for $\sim 100-260 \mathrm{~m}$ into basement. The final hole depth was to be determined by hole conditions and available time. The operations plan included wireline logging with a single string (to assess lithologic layering and properties and identify suitable locations for setting packers), testing for permeability using a drill string packer, and instrumenting the borehole with a multilevel CORK.

We planned to drill and case Hole U1362B (prospectus Site SR-2B) through sediment and the upper $\sim 30 \mathrm{~m}$ of basement, followed by $\sim 50 \mathrm{~m}$ of basement drilling with no coring or logging. A $24 \mathrm{~h}$ pumping and tracer injection experiment was scheduled to be completed before the borehole was instrumented with a CORK to monitor a single basement interval. Both of the Site U1362 CORK designs included instruments to monitor formation fluid pressure and temperature, sample fluids (using downhole and wellhead OsmoSamplers), and support microbial experiments.

\section{Site U1301}

The primary scientific objectives at Site U1301 were to recover the CORK instrument string deployed in Hole U1301B during Expedition 301 and deploy a new instrument string that included some combination of thermal sensors, fluid samplers, and microbial experiments. The extent of new instrumentation deployed in Hole U1301B was to depend on the amount of instrumentation recovered and the amount of space available in the $4 \frac{1}{2}$ inch CORK casing. Researchers were unable to recover the instrument string deployed in Hole U1301B in summer 2009 from the R/V Atlantis, despite pulling with a surface winch at $>5000 \mathrm{lb}$. Apparently, the instrument package was being held in the open hole below the CORK, probably because the borehole collapsed after the instrument string was originally deployed. We were hopeful that some instruments would be recovered from Hole U1301B because the coring line on the R/V JOIDES Resolution can be pulled with 
greater force than could the Plasma line used on the Atlantis. We also planned to complete a depth check of open casing in Hole U1301B and collect thermal data inside the CORK to evaluate the thermal state of the borehole surrounding the CORK installation following IODP Expedition 321T cementing operations.

\section{Site 1027}

The primary scientific objectives at Site 1027 were to recover the existing CORK in Hole 1027C, core and deepen the hole by $\sim 40-50 \mathrm{~m}$, run hydrologic tests of the open hole, and deploy a new multilevel CORK for monitoring, sampling, and associated experiments. The CORK in Hole 1027C was installed during Leg 168 and originally contained a data logger, pressure sensors, thermistors at multiple depths, and a fluid sampler. These instruments were retrieved in 1999, and the pressure logging system was replaced. The CORK in Hole $1027 \mathrm{C}$ was supposed to be replaced during Expedition 301, but problems setting the CORK in Hole U1301B and a lack of time and materials prevented completion of any Hole 1027C operations during that expedition. Hole $1027 \mathrm{C}$ was fully sealed and continued to record formation pressure before, during, and after Expedition 301.

\section{Site U1363}

Site U1363 (prospectus Sites GRB-1A, GRB-2A, and GRB-3A) was drilled adjacent to the northeastern edge of Grizzly Bare outcrop to test the hypothesis that this outcrop is a site of regional hydrothermal recharge. A short transect of holes extending radially away from Grizzly Bare outcrop was expected to show initial warming and a loss of oxygen and nitrate in basement fluids. Little change was expected for many of the major ions, even with elevated basement temperatures, because of the slow rate of reaction and the short residence time of formation fluids. The microbial population was expected to initially be predominantly that found in bottom seawater. Farther from Grizzly Bare, as dissolved oxygen and nitrate are depleted, we anticipated a decrease in sulfate as a result of diffusive loss to the overlying sediment during rapid lateral flow in basement. Observable changes were expected in additional major and minor elements and in the microbial communities living in sediments immediately above basement.

\section{Education, outreach, and communications objectives}

An international team of six education, outreach, and communication (EOC) personnel sailed during
Expedition 327, with leadership provided by the education director from the US Implementing Organization (USIO) and assistance from shore-based personnel. Earlier full-length scientific ocean drilling expeditions included a single onboard education officer who focused on a relatively small set of EOC objectives, whereas shorter expeditions or transits have included 12-18 teachers, faculty, and museum professionals who participated in shipboard activities while limited, if any, science operations were performed. The primary goals of the Expedition 327 EOC effort were to

1. Connect shipboard scientific, technical, and engineering personnel with nonspecialists on shore;

2. Develop K-12 curricula related to the expedition's scientific objectives and general earth and life science topics;

3. Create and distribute multimedia materials (written, photographic, video, and audio) related to expedition objectives and accomplishments; and

4. Help Expedition 327 scientific personnel learn to communicate the excitement of their research and other activities to an audience of nonscientists.

EOC personnel were also trained in shipboard scientific and technical tasks involving core analysis and collection of downhole data, which was helpful with core processing in the laboratories. The diverse EOC team included a high school physics teacher, a computer animation graduate student, an undergraduate engineering student representing Historically Black Colleges and Universities, an artist (all from the United States), and two high school earth and life science teachers from France selected by the European Consortium for Ocean Research Drilling (ECORD).

\section{Site summaries}

\section{Site U1362}

Hole U1362A was drilled and cored to 528 meters below seafloor (mbsf; 292 msb; Fig. F7), geophysically logged and hydrologically tested, and instrumented with a multilevel CORK observatory (Tables T1, T2, T3). Hole U1362B was drilled to $359 \mathrm{mbsf}$ (117 msb; Fig. F8), tested with a $24 \mathrm{~h}$ pumping and tracer injection experiment, and instrumented with a singlelevel CORK observatory.

Basement in Hole U1362A was cored from 346.0 to 496.0 mbsf (110-260 msb) with $44.4 \mathrm{~m}$ of core recovered (30\% recovery). Tides influence both apparent penetration rates and recovery of individual 
cores in basement (Fig. F9). It may take $2-6 \mathrm{~h}$ to cut a $9.5 \mathrm{~m}$ basement core, and sea level in the Expedition 327 work area can change by 1-3 m during this time. If the ship experiences a rising tide while drilling, some of the apparent penetration is a result of lowering the pipe as needed to keep weight on the bit. The opposite occurs when coring during a falling tide, making penetration appear to be less than it really is (as occurred with Core 327-U1362A-17R, which had an apparent recovery $>100 \%$; Fig. F9B). Over the length of an expedition, tidal influences generally average out, but penetration rates while coring or drilling are calculated using relatively short time intervals (minutes to hours), so tidal information is certainly mixed in with the penetration rate calculations made from rig instrumentation data.

The recovered core consisted of (1) aphyric to moderately phyric pillow basalts, (2) aphyric to sparsely phyric sheet flows, and (3) sparsely to highly phyric basalt flows (Fig. F10). The above lithologies were divided into eight units on the basis of changes in lava morphology, rock texture, and phenocryst occurrence. Pillow lava units (Units 1, 3, and 5) were subdivided according to changes in phenocryst abundance and mineralogy. Sheet flow units (Units 4, 6, and 8) were subdivided on the basis of the presence of chilled margins and variations in phenocryst mineralogy. No breccia units were recovered (only two centimeter-sized breccia pieces were recovered in total).

Pillow basalt is the most abundant flow morphology of Hole U1362A, with Units 1, 3, and 5 accounting for $78.85 \mathrm{~m}$ of the stratigraphy. Pillow basalt was primarily identified by the occurrence of curved glassy chilled margins with perpendicular radial cooling cracks. The basalt is sparsely to highly phyric with olivine, clinopyroxene, and plagioclase phenocrysts having spherulitic, hyalophitic, intersertal, and glomeroporphyritic textures. Pillow basalts range from sparsely to moderately vesicular, with a range of secondary minerals filling the vesicles. Alteration in the pillows is variable and ranges from slight to high.

Sheet flows are the second most common lava morphology in Hole U1362A and were classified on the basis of continuous sections of the same lithology that increase in grain size downward through the unit. Curated core recovery in these units averaged $43 \%$ and was as high as $112 \%$ in Core $327-\mathrm{U} 1362 \mathrm{~A}-$ 17R. Two near-continuous sheet flows were recovered in Cores 17R and 18R and were divided into two subunits on the basis of a change in phenocryst mineralogy. The primary mineralogy of the sheet flows is very similar to that of the pillow basalts, comprising a range of aphyric to moderately phyric basalt with olivine, clinopyroxene, and plagioclase phenocrysts. Grain size within the sheet flows ranges from cryptocrystalline to fine grained, and textures vary from intersertal to intergranular. The sheet flows are nonvesicular to highly vesicular, with some flows exhibiting a similar abundance throughout and others having high variability within a single flow. Alteration within the sheet flows varies from slight to complete. Fracture and vein intensity within the sheets flows is lower than in the pillow basalts and resulted in improved core recovery and larger individual pieces.

The third lithologic type of basalt flow was classified on the basis of the absence of definitive morphological features associated with either pillow lavas or sheet flows, allowing only a general "basalt flow" interpretation to be made. These units are aphyric to moderately phyric crypto- to microcrystalline basalt with the same primary mineralogy as all basalts from Hole U1362A. They are generally sparsely vesicular with secondary minerals filling vesicles, and textures vary from hyalophitic to variolitic. Alteration is moderate to high and is present as groundmass replacement (mesostasis and phenocrysts), vesicle fill, vein formation, and halos.

Two individual pieces of breccia were recovered: a hyaloclastite sample in Core 327-U1362A-13R and a cataclastic zone in Core 327-U1362A-9R. The hyaloclastite is characterized by moderately to highly altered angular clasts in a saponite and altered glass matrix. The cataclastic zone is formed of subangular clasts with moderate alteration similar to the host rock and exhibits evidence of clast rotation and separation with a matrix of highly altered ground basalt.

The lithostratigraphy developed for Hole U1362A is somewhat different from that developed for Hole U1301B, located only $800 \mathrm{~m}$ to the south (Fig. F10). Compared to Hole U1301B, core from Hole U1362A contains considerably greater fractions of sheet flows and basalt flows (called "massive basalt" and "basalt lava," respectively, for Hole U1301B) and evidence for more extensive and higher temperature hydrothermal alteration. Hole U1362A also contains less hyaloclastite breccia; however, only five coherent pieces of this rock type were recovered from Hole $\mathrm{U} 1301 \mathrm{~B}$, and it seems likely that much more of this fragile rock type was present but not recovered from the formation in both locations.

Geochemical analyses of basalt samples indicate that they are all normal depleted mid-ocean-ridge basalt (N-MORB) and are inferred to all have the same magmatic source on the basis of cross-plots of $\mathrm{TiO}_{2} \mathrm{vs}$. Zr. Hydrothermal alteration of basement varying from 
slight to complete was observed in all basalts from Hole U1362A, with the majority moderately altered. Alteration of the rocks manifests in four ways: (1) replacement of phenocrysts, (2) replacement of groundmass (mostly mesostasis), (3) filling of veins and adjacent alteration halos, and (4) lining and filling of vesicles. In thin section, alteration was observed to range from $8 \%$ to $91 \%$. Away from vesicles and veins, background alteration is generally moderate to high in pillow lavas and predominantly moderate in sheet and basalt flows and is dominated by saponitic background alteration. Olivine is present only as completely replaced pseudomorphs.

The secondary mineralogy is dominated by clay minerals that are present in all four types of alteration. Saponite is the most abundant of the clay minerals and is present as black, dark green, greenishbrown, and pale blue colors and in thin section is characterized by a pale brown color and mottled or fibrous form. Celadonite is also present in all four types of alteration but is less abundant than saponite. In thin section, celadonite is bright green, and within some vesicles the color varies in intensity, reflecting a mix of saponite and celadonite. Iron oxyhydroxide is the second most abundant secondary phase, occurring both alone as iron oxyhydroxides and mixed with saponite and other clay phases to form iddingsite. Iron oxyhydroxides are identifiable by a bright orange to red color and often stain other phases present. Zeolite phillipsite was identified by $\mathrm{X}$-ray diffraction analysis of mixed veins and altered chilled margins in addition to montmorillonite (smectite group) from veins. Carbonate is present as vesicle fill, in veins, and within chilled margins and predominantly occurs mixed with clays and occasionally sulfides. Anhydrite is rarely present in veins from Subunit 6B.

A total of 1230 veins were logged, with an average frequency of 27 veins per meter of recovered core. Vein width ranges from $<0.1$ to $4 \mathrm{~mm}$, and vein morphology is variable. Saponite is the most abundant vein fill and is present in $76 \%$ of the veins, with unidentified clay minerals filling $50 \%$ of veins. The next most abundant vein fill is iron oxyhydroxides, which fill $32 \%$ of veins. Carbonate and pyrite are present in $10 \%$ of veins but are only occasionally the dominant components. Celadonite occurs in $2 \%$ of veins and is a larger component of the background alteration. Rare anhydrite veins are present within Subunit 6B. Alteration halos flank 15\% of hydrothermal veins and are otherwise found flanking rock edges or apparently unassociated from structural features. Halos range from single-color black, green, or orange halos to complex multihalos with mixed colors.

The dips of 519 veins and fractures were measured, and three types of fractures were distinguished: (1) veins flanked by alteration halos (haloed veins), (2) veins not flanked by alteration halos but filled with secondary minerals (nonhaloed veins), and (3) joints sometimes flanked by alteration halos but not filled with minerals. Nonhaloed veins were the most frequently observed structures. Nonhaloed veins were identified mainly in the massive lavas and in some pillow-lava pieces. No faults or shear veins with any evidence of displacement were found.

In addition to cores recovered from Hole U1362A, small millimeter- to centimeter-sized chips were recovered from the drill bit in Holes U1362A and U1362B. In both cases the drill bit penetrated only a few meters below the sediment/basalt interface before being pulled to the rig floor, where the drill cuttings were removed. The source of the drill cuttings can be constrained to a short interval at this interface and represents the only recovery of basement material at the sediment/basalt interface at Site U1362. Basalt exhibiting a wide variety of hydrothermal alteration was recovered in these chips, and similar compositions were recovered in both Holes U1362A and U1362B. Alteration types included pervasive green and red alteration, iron oxyhydroxides, pale gray sulfide-bearing mud, and basalt chips with epidote crystals. The occurrence of epidote with pyrite at the seafloor, combined with anhydrite at depth, may indicate that Hole U1362A was formerly a location of hydrothermal upflow.

Whole-round basalt core sections were run through the Whole-Round Multisensor Logger (WRMSL) and Natural Gamma Radiation Logger (NGRL) prior to splitting. Gamma ray attenuation (GRA) density data vary widely as a result of unfilled core liners in sections with poor recovery. Despite this, peak bulk density values are consistent at $\sim 2.5 \mathrm{~g} / \mathrm{cm}^{3}$ for much of the core recovered. For the more cohesive, massive sections recovered in deeper cores, GRA results are slightly higher than $2.5 \mathrm{~g} / \mathrm{cm}^{3}$. Magnetic susceptibility measurements also vary widely, ranging from 0 to $3300 \times 10^{-6} \mathrm{SI}$. Total counts from the NGRL are generally low (1-5 counts/s). For all measurements, the highest values were found in massive sections, with other lithologies, namely pillow lavas and basalt flows, generally yielding much lower values.

Thermal conductivity was tested in three samples from the uppermost section of pillow basalts, yielding values of $1.63,1.67$, and $1.72 \mathrm{~W} /(\mathrm{m} \cdot \mathrm{K})$ at depths 
of 349,354 , and 355 mbsf, respectively. These values compare well with data collected at similar depths in nearby Hole U1301B $(1.70 \pm 0.09 \mathrm{~W} /[\mathrm{m} \cdot \mathrm{K}])$. Problems with the thermal conductivity half-space system prevented additional measurements.

$P$-wave velocities were measured on 70 discrete samples. $P$-wave velocity values determined by manual picking of the first arrival range from 4.5 to $6.0 \mathrm{~km} / \mathrm{s}$, with an average of $\sim 5.4 \mathrm{~km} / \mathrm{s}$. The average value is greater than values obtained from Hole U1301B. The lowest velocity was measured on a heavily altered sample (327-U1362A-14R-1, 11-13 cm). A test of nearby unaltered material yielded much higher velocity, which demonstrates the influence of rock alteration on $P$-wave velocity. We found no statistically significant overall velocity trend with depth or overall velocity anisotropy depending on sample direction.

Moisture and density properties were determined on 73 discrete samples from Hole U1362A. Bulk density values range from 2.2 to $2.9 \mathrm{~g} / \mathrm{cm}^{3}$, with an average of $\sim 2.7 \mathrm{~g} / \mathrm{cm}^{3}$ (Fig. F10). Grain density values range from 2.4 to $3.0 \mathrm{~g} / \mathrm{cm}^{3}$, with a mean of $\sim 2.9 \mathrm{~g} / \mathrm{cm}^{3}$. Porosity values range from $2.8 \%$ to $15.0 \%$, with a mean of $7.9 \%$. The highest value of porosity was obtained from a highly altered sample that also had the lowest velocity. Overall, $P$-wave velocity and porosity are inversely correlated.

Twenty-five whole-round samples (4-20 cm long) were collected for microbiological analysis. Samples were preserved for shore-based DNA analysis, fluorescent in situ hybridization (FISH) and cell counting analysis, and fluorescent microsphere analysis. One sample was also collected for shore-based analysis of particulate organic carbon and nitrogen as well as carbon and nitrogen isotopic compositions. Hard rock samples span a range of lithologic units, alteration states, and presence of chilled margins, and most contain at least one vein per fracture. Additionally, a few recovered plastic bags that held fluorescent microspheres were collected as a contamination check for DNA analysis. Colonization experiments were assembled for the Hole U1362A and U1362B CORK instrument strings. Fluid samples were collected for shore-based microbiological analysis during the $24 \mathrm{~h}$ tracer injection experiment in Hole U1362B.

Remanent magnetization measurements were made on 79 discrete pieces and on portions of 23 core sections. Samples were demagnetized at 5 or $10 \mathrm{mT}$ steps from 0 to $50 \mathrm{mT}$ using the cryogenic magnetometer's inline alternating-field (AF) coils. Most samples display simple magnetization behavior. Principal component analyses were performed on select samples. The majority of samples have positive inclinations, indicating that magnetization was acquired during a normal polarity period, consistent with the age of the crust at this location. Some samples have steep positive inclinations that might be influenced by a drilling overprint. A few samples have reverse magnetizations, which are most likely the result of alteration. Inclinations are scattered around $460-470$ mbsf in Unit 6.

A single wireline logging string was deployed in Hole U1362A to resolve physical and hydrological properties and identify suitable intervals for packer installation. The logging string consisted of a qualitative spontaneous potential electrode and sensors for measuring natural spectral gamma ray, bulk density, borehole fluid temperature, tool orientation, tool motion, ultrasonic borehole images, and hole diameter. Two passes were run over the entire open hole section, and a third pass was run over two intervals of particular interest. Seven logging units were identified on the basis of petrophysical log response and borehole conditions.

Both the mechanical and ultrasonic calipers revealed a borehole that was highly enlarged over most of the open hole section (Fig. F10). Notable near-gauge sections were identified at 417 and 447 mbsf. Good conditions were expected in these sections on the basis of rotary core barrel recovery and by the apparent coring and drilling rates of penetration. Low recovery and higher rates of penetration correlate well with an enlarged borehole. Where the ultrasonic caliper values appear meaningful, they indicate a nearly circular borehole through the near-gauge intervals.

A comparison of caliper logs and apparent penetration rates from Holes U1362A, U1362B, and U1301B suggests that there is some along-strike, lateral continuity in major basement units (Fig. F11). The uppermost $100 \mathrm{~m}$ of basement in all holes at Sites U1301 and U1362 was drilled without coring using a $14 \% 4$ inch drill bit, and the lower parts of Holes U1362A and U1362B were drilled with a 97/8 inch drill bit rather than a coring bit, so quantitative comparison of penetration rates in individual holes can be difficult. Nevertheless, the rapid penetration rate achieved in the uppermost $100 \mathrm{~m}$ of basement at Sites U1301 and U1362 is consistent with the rubbly and oversized character of the resulting boreholes and difficulties encountered when deploying 103/4 inch casing (Fig. F11).

The ultrasonic borehole images are marred by rotational and heave-induced tool motion. In addition, the ultrasonic tool's sonde head is undersized for these borehole diameters, and, where Hole U1362A is enlarged, no meaningful images can be expected. Certain fractures and other features were observed in the 447 mbsf near-gauge section, particularly during 
the third imaging pass made at the highest vertical resolution.

The density readings were impaired by poor borehole conditions in many intervals. Where hole condition was good, logged density compares favorably with density measurements on discrete core samples (Fig. F10).

Gamma ray measurements in the basaltic crust are driven by potassium content and were repeatable over the three passes. Where increases in gamma ray values correspond with enlarged borehole intervals, such as the one at 470 mbsf, they may represent zones of greater alteration and may be indicative of focused hydrothermal fluid flow. A pronounced gamma ray deflection was observed at and above the $103 / 4$ inch casing shoe, likely a measure of trace uranium and thorium in the cement used to isolate the borehole.

Borehole fluid temperature data were acquired while running into the hole and during the three upward logging passes. The borehole temperature gradient increases steeply at the top of the 447 mbsf neargauge interval, and a $0.5^{\circ} \mathrm{C}$ temperature anomaly was observed $8 \mathrm{~m}$ below the casing shoe.

Packer experiments were completed in Hole U1362A to assess the permeability of the formation. The sealed-hole pressure baseline was recorded for $1 \mathrm{~h}$, and two $1 \mathrm{~h}$ long injection tests were conducted, each followed by $1 \mathrm{~h}$ to allow the pressure to recover to baseline conditions. Preliminary data analysis indicates a bulk permeability consistent with that in nearby Hole U1301B (Becker and Fisher, 2008).

A $24 \mathrm{~h}$ pumping and tracer injection experiment was conducted prior to the CORK deployment in Hole U1362B (Fisher, Cowen, et al.). OsmoSamplers and pressure gauges were deployed in a specially designed stinger sub just below the casing shoe in the open hole. After waiting $1 \mathrm{~h}$ to allow the hole to equilibrate, seawater was pumped into the formation at a rate of 20 strokes per minute ( $7 \mathrm{~L} / \mathrm{s})$ (Fig. F12). At 1 and $20 \mathrm{~h}$ into the experiment, freshwater instead of seawater was pumped into the formation for $1 \mathrm{~h}$. The tracers injected included $\mathrm{SF}_{6}$ gas (for $\sim 22 \mathrm{~h}$ ), $\mathrm{CsCl}$ and $\mathrm{ErCl}_{3}$ salts (at $3 \mathrm{~h}$ ), $\mathrm{CsCl}$ and $\mathrm{HoCl}_{3}$ salts (at $19 \mathrm{~h}$ ), fluorescent microspheres (at $20 \mathrm{~h}$ ), and stained bacteria (at $21 \mathrm{~h}$ ) extracted from sea-surface water. Pumping ceased during the last hour of the experiment so the hole could equilibrate again. The pressure record will require considerable processing to account for tides and changes in fluid density associated with switching from freshwater to saltwater and with the injection of salts as part of the tracer experiment. Rig floor and stinger fluid samples were collected during tracer injection, and shore-based analysis will be required to develop a detailed history of injectate chemistry and particle concentration during the test. Pressure data and chemical samples will be collected from CORKs in this area in summer 2011, which will provide the first information from scientific ocean drilling on hole-to-hole solute and particle velocities.

The CORKs deployed during Expedition 327 are modified from the CORK-II design prepared for Expedition 301. The Hole U1362A CORK monitors two basement intervals: a shallow interval extending from the base of the $103 / 4$ inch casing to the top of the deepest set of swellable packers (307.5-417.5 mbsf) and a deeper interval extending from the base of the deepest inflatable packer to the bottom of the hole (429.2-528.0 mbsf) (Fig. F13). Pressure in both intervals is monitored through $1 / 4$ inch stainless steel tubing connected to miniscreens installed just below the inflatable packers at the top of the isolated intervals. Three $1 / 2$ inch stainless steel fluid sampling lines terminated at two depths (two below packers in the upper interval and one below packers in the lower interval). A single $1 / 2$ inch polytetrafluoroethylene (PTFE) microbiology sampling line ends in a titanium miniscreen that rests on perforated and coated $5 \frac{1}{2}$ inch casing, $7 \mathrm{~m}$ below the base of the deepest inflatable packer, just above the perforated collars. The downhole instrument string includes 6 OsmoSamplers and microbial growth incubators positioned within the coated perforated $5 \frac{1}{2}$ inch casing and collars, 11 autonomous temperature probes, a $200 \mathrm{lb}$ sinker bar, and a plug to seal the hole near the seafloor.

The Hole U1362B CORK monitors a single basement interval that extends from a single set of swellable and inflatable packers positioned just inside the base of the $103 / 4$ inch casing to the bottom of the hole (272-359 mbsf) (Fig. F13). Pressure in this interval is monitored via a $1 / 4$ inch stainless steel tube connected to a miniscreen installed just below the inflatable packers. The intakes of the three $1 / 2$ inch stainless steel fluid sampling lines are located on perforated and coated $5 \frac{1}{2}$ inch casing, about $3 \mathrm{~m}$ below the packers, providing sampling redundancy. A single $1 / 2$ inch PTFE microbiology sampling line ends in a titanium miniscreen that rests on perforated and coated $5 \frac{1}{2}$ inch casing, $7 \mathrm{~m}$ below the base of the deepest inflatable packer, just above the perforated collars. The downhole instrument string comprises six OsmoSamplers and microbial growth incubators, eight autonomous temperature probes, a $200 \mathrm{lb}$ sinker bar, and a plug to seal the hole near the seafloor.

Both CORKs include a large-diameter ball valve in the wellhead that can be opened to allow fluids to 
bypass the top plug through a "lateral" pipe that extends from the main CORK tubing above the seafloor seal ("L-CORK" design). Researchers will initiate a long-term flow experiment in summer 2011 by deploying a flow meter and opening the ball valve on one of the Site U1362 CORKs using the ROV Jason. Flow will continue for at least $1 \mathrm{y}$, allowing testing of a much larger volume of crust than has been tested previously during scientific ocean drilling experiments.

\section{Site U1301}

We recovered an incomplete portion of the instrument string deployed during Expedition 301, comprising five autonomous temperature loggers and part of the Spectra cable (Tables T1, T2, T3; see "Operations" in the "Site U1301" chapter). The rest of the instrumentation was left in the CORK or hole. Of the five autonomous temperature loggers recovered from Hole U1301B, one was able to communicate and download data during Expedition 327. All of the tools were deployed well beyond their intended 4$5 \mathrm{y}$ battery life. The four nonoperational tools were returned to the manufacturer for servicing and data download (data are stored in nonvolatile memory). The tool that did provide data showed that temperatures at depth began to rise beginning in summer 2009, soon after cementing during Expedition 321T. In addition, a temperature log collected in the upper $364 \mathrm{~m}$ of the open CORK casing shows that the thermal gradient in Hole U1301B has nearly returned to a predrilling state. Collectively, these data suggest that the remedial cementing conducted in summer 2009 during Expedition 321T was successful in sealing the hole. A short instrument string with three temperature loggers was deployed in Hole U1301B and will be useful in assessing the continued thermal rebound of the hole.

\section{Site 1027}

No scientific results were obtained at Site 1027 as a result of the failed attempt to recover the CORK installed during Leg 168 (see "Operations" in the "Site 1027" chapter).

\section{Site U1363}

Five holes were cored at Site U1363, adjacent to the edge of Grizzly Bare outcrop (Tables T1, T2, T3; Figs. F3B, F14). Sediments are composed of turbidites interspersed with hemipelagic clay, consistent with core recovery during Leg 168 and Expedition 301 (Davis, Fisher, Firth, et al., 1997; Fisher, Urabe, Klaus, and the Expedition 301 Scientists, 2005). Four lithologic units were distinguished (Fig. F14).
Unit 1 is composed of hemipelagic mud (clayey silt to silty clay), thin-bedded turbidites (sand-silt-clay), and thick-bedded medium sand turbidites. Unit 2 is composed of beds of silt and sandy silt intercalated with hemipelagic mud deposits (silty clay to clayey silt). Unit 3 is composed of hemipelagic carbonaterich claystone rich in foraminifers and nannofossils. Unit 4 is represented by a few small pieces of basalt recovered from the sediment/basalt interface in Holes U1363B, U1363D, and U1363F. The basalt is cryptocrystalline and plagioclase phyric, with glomeroporphyritic texture visible in hand specimens. Phenocrysts are large (up to $8 \mathrm{~mm}$ ) and are anhedral to euhedral in shape. The basalt is sparsely vesicular with highly variable vesicle size and shape. Secondary minerals are present as background groundmass replacement and alteration halos as well as filling vesicles and lining hydrothermal veins.

All cores were run through the WRMSL, yielding magnetic susceptibility values from $<500 \times 10^{-6} \mathrm{SI}$ in clay sections to $\sim 1400 \times 10^{-6}$ SI in sandy turbidites. Point magnetic susceptibility data collected with the Section Half Multisensor Logger (SHMSL) are similar, with split-core values tending to be slightly lower than whole-round values, except in the case of turbidite sequences, where SHMSL values are consistently higher. GRA bulk density averages $\sim 1.8 \mathrm{~g} / \mathrm{cm}^{3}$, depending on lithology, with some compaction evident with depth in clay data. $P$-wave velocities measured on the WRMSL range from $\sim 1.46$ to $\sim 1.87 \mathrm{~km} / \mathrm{s}$, excluding the erroneously low values derived from insufficient sediment filling within core liners.

Discrete measurements, including moisture and density (MAD), $P$-wave velocity, and thermal conductivity, were measured on most cores from Holes U1363B-U1363D and U1363F. Insufficient time was available to measure samples from Hole U1363G. Thermal conductivity at Site U1363 averages $1.3 \pm$ $0.2 \mathrm{~W} /(\mathrm{m} \cdot \mathrm{K})$, whereas MAD bulk densities average $1.7 \mathrm{~g} / \mathrm{cm}^{3}$, both showing bimodal distributions corresponding to clay and sand lithologies. MAD porosities range from $38 \%$ to $76 \%$, with an average value of $\sim 60 \%$. $P$-wave velocities of discrete samples range from 1.49 to $1.75 \mathrm{~km} / \mathrm{s}$ (mean $=\sim 1.52 \mathrm{~km} / \mathrm{s}$ ), with considerable variability across lithologies. The velocities derived from discrete measurements agree with those measured on whole-round sections with the WRMSL. Velocities also show weak anisotropy between vertical and horizontal directions. $P$-wave velocity increases $\sim 50 \mathrm{~m} / \mathrm{s}$ within the uppermost 50 mbsf. On the other hand, grain density is remarkably consistent regardless of depth or lithology.

Pore water samples were recovered from five holes, providing systematic trends to assess the composi- 
tion of the underlying basaltic formation fluid at these locations. Pore waters were extracted in a nitrogen atmosphere, and some analyses (alkalinity and ion chromatography) were conducted immediately to guide subsequent drilling operations. We collected 58 pore water samples: 15 from Hole U1363G, 14 from Hole U1363F, 14 from Hole U1363B, and 15 from (adjacent) Holes U1363C/U1363D, with basement depths of 17, 35, 57, and $231 \mathrm{mbsf}$, respectively. In the upper portion of the sediment, biogenic processes release dissolved $\mathrm{Mn}$ and Fe near the sediment/water interface and consume sulfate. There is a corresponding increase in alkalinity, phosphate, and ammonium and an initial decrease in Ca resulting from carbonate formation given the high alkalinity values. Similar trends for sulfate, Mn, and Fe exist near the sediment/basalt interface. However, phosphate and ammonium are more influenced by diffusion and reaction within the upper basaltic basement. The cations $\mathrm{Ca}, \mathrm{Mg}$, and $\mathrm{K}$ show gradients near the sediment/basalt interface, indicative of a formation fluid that is slightly altered relative to seawater. Minor and trace elements in seawater also show gradients in the basal sediment section, with greater alteration at greater distance from the outcrop.

Microbiologists collected whole-round core and pore water samples from sediments and basement pieces recovered at Site U1363. Eleven sediment intervals were targeted for microbiology sampling in Hole U1363B. Most samples were taken from hemipelagic clay layers, although some sandy turbidite layers were also sampled. The deepest sediment sample was taken from a carbonate-rich layer near the sediment/ basalt interface. Thirteen sediment intervals and one basement basalt interval were sampled from Holes U1363C and U1363D. Again, sediment samples were mostly from clay-rich layers, although some samples contained sand. The basement sample from Core 327-U1363D-6X was a relatively unfractured basalt with spots of light green and orange alteration crusts. Nineteen sediment and basement samples were taken from Hole U1363F. Most samples contained either clay or sandy layers, with the exception of samples from Section 327-U1363F-4H-2 and deeper, which also contained manganese crust, basalt fragments, and lighter tan-colored sediment resembling the foraminifer-rich carbonate sediments from Hole U1363B. Sixteen samples were collected from Hole U1363G. All samples were clay rich, and no hard rock samples were recovered.

At each sampling location, whole-round core samples were collected for shore-based DNA analysis, characterization of halogenated organic matter, and incubation experiments to examine dehalogenation reaction activities. Syringe samples were also collected for headspace gas analysis and microsphere contamination checks from the interior and exterior of the cores. Headspace samples were analyzed on board for safety purposes, and only a few samples contained quantifiable levels of methane or higher hydrocarbon gases. Microsphere samples were shipped to the shore-based laboratory for postcruise analysis because of time limitations at the end of the expedition. These samples will also be used for shore-based cell counting analysis and FISH analysis. A subset of samples was collected for analyses of dissolved organic carbon/dissolved nitrogen, particulate organic carbon/particulate nitrogen, amino acids, low molecular weight organic acids, and lipid biomarkers.

Remanent magnetization measurements were made on two-thirds of core sections from Hole U1363B. Samples were demagnetized at $10 \mathrm{mT}$ steps from 0 to $40 \mathrm{mT}$ using the cryogenic magnetometer's inline AF coils. Although the majority of samples have positive inclinations, there is a large scatter of positive and negative inclinations, which is probably the result of core disturbance during coring and the alternating sequences of hemipelagic mud and turbidite deposits.

Temperature measurements were collected with the third-generation advanced piston corer temperature tool (APCT-3) and the Sediment Temperature (SET) tool in Holes U1363B-U1363E. Good measurements were obtained with both tools, and these data will be analyzed postexpedition to assess seafloor heat flow and thermal conditions in basement.

\section{Education, outreach, and communications summary}

EOC, scientific, and technical personnel participated in an initial seminar on constructivist and inquirybased education methods, and EOC personnel followed up with several weeks of exercises to investigate earth science concepts to gain a foundation in the regional geology and scientific objectives of the expedition. Projects outlined in general terms during precruise webinars were clarified, and strategies were developed for completing them.

Progress reports and meetings were conducted every 2 weeks to facilitate and modify plans, as needed, and to assess achievements. Independence and constructivist learning were emphasized, allowing individuals to work on projects that were beneficial to their future goals and to the ocean drilling community and whose success relied on each person's set of skills. Projects ranged from earth science classroom 
activities to computer learning interactives, demonstrations on robotics, computer animation, and science-related fine arts. More than 70 individual activities were completed and are ready for testing with teachers and students.

The shipboard EOC team advanced the scientific goals of the expedition and of IODP by communicating the importance of scientific ocean drilling to a broad external audience and engendering understanding and enthusiasm for scientific exploration, ocean drilling, and subseafloor observatories. This was accomplished in partnership with the science party. Toward this objective, the team worked with blogs, up-to-the-minute social media, and live video interactions with schools and museums. More than 90 blog posts in English and French were added to joidesresolution.org/ (USIO website oriented toward a nonscientific audience) by eight authors. Ohio teacher Jackie Kane's blogs were notable for the close one-on-one dialogue she maintained with students and her rapid and thorough responses to comments (Fig. F15A). Kane's page ranked second only to the home page, with 1257 views during August, or $7.5 \%$ of the total 16,660 page views. Overall, joidesresolution.org/ visitorship and use increased $40 \%$ in July compared to the previous 2 months, with $\mathrm{Au}$ gust bringing 2435 new visitors to the site (Fig. F15D).

The Adopt-A-Microbe from the Deep Biosphere website (spearheaded by Expedition 327 microbiologist Beth Orcutt), attracted and engaged numerous visitors, introducing them to the nature of dark biosphere research (sites.google.com/site/adoptamicrobe/) (Orcutt et al., submitted). This website is notable for its rich variety of formats and activities, and it attracted numerous visitors, many of whom participated in weekly hands-on activities and submitted their results to the site. As one of the first IODP education and outreach activities focused on communicating the exciting discoveries being made about microbial life in the deep biosphere, the Adopt-AMicrobe model will be replicated and incorporated into future expedition education and outreach activities. This website was linked to joidesresolution.org/, as was scientist Amanda Turner's blog for eighth grade special education students in Phoenix, Arizona. Turner's blog resulted in a set of engaging math and science-related interviews with scientists and other shipboard personnel, emphasizing the importance of mathematics and science in careers. These interviews will be added to the joidesresolution.org/ career interactive later this year, along with adaptive activities for special needs students. The team also focused on outreach through the JOI-
DES Resolution and Deuxprofsembarques Joides Facebook pages, the JOIDES Resolution Twitter page, and four YouTube videos (two videos showed operations related to CORK and OsmoSampler deployments, the third video was an animation that depicted postdrilling operations at a CORK wellhead, and the fourth presented a scientific overview of CORKs; see MOVIES in "Supplementary material").

EOC team members conducted 15 live video events for approximately 500 participants at museums, summer camp groups, and schools in the United States (California, Florida, New Jersey, Ohio, Pennsylvania, Tennessee, Texas, and Washington, DC), France, and New Caledonia. Further information will be collected through user surveys, but anecdotal and qualitative information, as well as increased social media and website activity immediately following these video events, suggest generally positive response to the fast-paced virtual tours of shipboard laboratories and interviews with scientific, technical, and engineering staff. Noteworthy broadcasts included women on the ship talking with high school girls at a career-focused summer camp, shipboard educators talking directly to their students, and an all new safety-oriented ship and laboratory tour intended to introduce New Jersey eighth graders to the use of personal protective equipment, fire drills, and accident reporting. Other novel outreach contributions during Expedition 327 include a live-action video introducing CORK technology and experimental goals crafted by scientific personnel and forwarded in advance of videoconferences, an animated presentation of drilling and CORK technology to be used for public and scientific outreach, audio podcasts featured on the Centers for Ocean Sciences Education Excellence (COSEE)-sponsored OceanGazing podcast site, and two video conferences conducted with the research vessels $\mathrm{D} / \mathrm{V}$ Chikyu and $\mathrm{R} / \mathrm{V}$ Thompson.

\section{References}

Alt, J.C., 1995. Subseafloor processes in mid-ocean ridge hydrothermal systems. In Humphris, S.E., Zierenberg, R., Mullineaux, L., and Thomson, R. (Eds.), Seafloor Hydrothermal Systems: Physical, Chemical, Biological and Geological Interactions within Hydrothermal Systems. Geophys. Monogr., 91:85-114.

Becker, K., and Fisher, A.T., 2008. Borehole packer tests at multiple depths resolve distinct hydrologic intervals in 3.5-Ma upper oceanic crust on the eastern flank of Juan de Fuca Ridge. J. Geophys. Res., [Solid Earth], 113(B7):B07105. doi:10.1029/2007JB005446

Carbotte, S.M., Nedimovic, M.R., Canales, J.P., Kent, G.M., Harding, A.J., and Marjanovic, M., 2008. Variable 
crustal structure along the Juan de Fuca Ridge: influence of on-axis hot spots and absolute plate motions. Geochem., Geophys., Geosyst., 9:Q08001. doi:10.1029/ 2007GC001922

Davis, E.E., Chapman, D.S., Mottl, M.J., Bentkowski, W.J., Dadey, K., Forster, C., Harris, R., Nagihara, S., Rohr, K., Wheat, G., and Whiticar, M., 1992. FlankFlux: an experiment to study the nature of hydrothermal circulation in young oceanic crust. Can. J. Earth Sci., 29(5):925-952.

Davis, E.E., Chapman, D.S., Wang, K., Villinger, H., Fisher, A.T., Robinson, S.W., Grigel, J., Pribnow, D., Stein, J., and Becker, K., 1999. Regional heat flow variations across the sedimented Juan de Fuca Ridge eastern flank: constraints on lithospheric cooling and lateral hydrothermal heat transport. J. Geophys. Res., [Solid Earth], 104(B8):17675-17688. doi:10.1029/1999JB900124

Davis, E.E., Fisher, A.T., Firth, J.V., et al., 1997. Proc. ODP, Init. Repts., 168: College Station, TX (Ocean Drilling Program). doi:10.2973/odp.proc.ir.168.1997

Elderfield, H., and Schultz, A., 1996. Mid-ocean ridge hydrothermal fluxes and the chemical composition of the ocean. Annu. Rev. Earth Planet. Sci., 24(1):191-224. doi:10.1146/annurev.earth.24.1.191

Elderfield, H., Wheat, C.G., Mottl, M.J., Monnin, C., and Spiro, B., 1999. Fluid and geochemical transport through oceanic crust: a transect across the eastern flank of the Juan de Fuca Ridge. Earth Planet. Sci. Lett., 172(1-2):151-165. doi:10.1016/S0012821X(99)00191-0

Fisher, A.T., Davis, E.E., and Becker, K., 2008. Borehole-toborehole hydrologic response across $2.4 \mathrm{~km}$ in the upper oceanic crust: implications for crustal-scale properties. J. Geophys. Res., 113(B7):B07106. doi:10.1029/ 2007JB005447

Fisher, A.T., Davis, E.E., Hutnak, M., Spiess, V., Zühlsdorff, L., Cherkaoui, A., Christiansen, L., Edwards, K., Macdonald, R., Villinger, H., Mottl, M.J., Wheat, C.G., and Becker, K., 2003. Hydrothermal recharge and discharge across $50 \mathrm{~km}$ guided by seamounts on a young ridge flank. Nature (London, U. K.), 421(6923):618-621. doi:10.1038/nature01352

Fisher, A.T., Tsuji, T., and Gamage, K., 2010. Juan de Fuca Ridge-Flank Hydrogeology: the hydrogeologic architecture of basaltic oceanic crust: compartmentalization, anisotropy, microbiology, and crustal-scale properties on the eastern flank of Juan de Fuca Ridge, eastern Pacific Ocean. IODP Sci. Prosp., 327. doi:10.2204/ iodp.sp.327.2010

Fisher, A.T., Urabe, T., Klaus, A., and the Expedition 301 Scientists, 2005. Proc. IODP, 301: College Station, TX (Integrated Ocean Drilling Program Management International, Inc.). doi:10.2204/iodp.proc.301.2005

Fisher, A.T., and Von Herzen, R.P., 2005. Models of hydrothermal circulation within 106 Ma seafloor: constraints on the vigor of fluid circulation and crustal properties, below the Madeira Abyssal Plain. Geochem., Geophys., Geosyst., 6(11):Q11001. doi:10.1029/2005GC001013

Fisher, A.T., Wheat, C.G., Becker, K., Davis, E.E., Jannasch, H., Schroeder, D., Dixon, R., Pettigrew, T.L., Meldrum, R., McDonald, R., Nielsen, M., Fisk, M., Cowen, J., Bach,
W., and Edwards, K., 2005. Scientific and technical design and deployment of long-term, subseafloor observatories for hydrogeologic and related experiments, IODP Expedition 301, eastern flank of Juan de Fuca Ridge. In Fisher, A.T., Urabe, T., Klaus, A., and the Expedition 301 Scientists, Proc. IODP, 301: College Station, TX (Integrated Ocean Drilling Program Management International, Inc.). doi:10.2204/ iodp.proc.301.103.2005

Huber, J.A., Johnson, H.P., Butterfield, D.A., and Baross, J.A., 2006. Microbial life in ridge flank crustal fluids. Environ. Microbiol., 88(1):88-99. doi:10.1111/j.14622920.2005.00872.x

Hutnak, M., Fisher, A.T., Zühlsdorff, L., Spiess, V., Stauffer, P.H., and Gable, C.W., 2006. Hydrothermal recharge and discharge guided by basement outcrops on 0.7-3.6 Ma seafloor east of the Juan de Fuca Ridge: observations and numerical models. Geochem., Geophys., Geosyst., 7(7):Q07O02. doi:10.1029/2006GC001242

Johnson, H.P., and Pruis, M.J., 2003. Fluxes of fluid and heat from the oceanic crustal reservoir. Earth Planet. Sci. Lett., 216(4):565-574. doi:10.1016/S0012821X(03)00545-4

Mottl, M.J., 2003. Partitioning of energy and mass fluxes between mid-ocean ridge axes and flanks at high and low temperature. In Halbach, P.E., Tunnicliffe, V., and Hein, J.R. (Eds.), Energy and Mass Transfer in Marine Hydrothermal Systems: Berlin (Dahlem Univ. Press), 271286.

Mottl, M.J., Wheat, G., Baker, E., Becker, N., Davis, E., Feely, R., Grehan, A., Kadko, D., Lilley, M., Massoth, G., Moyer, C., and Sansone, F., 1998. Warm springs discovered on 3.5 Ma oceanic crust, eastern flank of the Juan de Fuca Ridge. Geology, 26(1):51-54. doi:10.1130/ 0091-7613(1998)026<0051:WSDOMO >2.3.CO;2

Nedimovic, M.R., Carbotte, S.M., Diebold, J.B., Harding, A.J., Canales, J.P., and Kent, G.M., 2008. Upper crustal evolution across the Juan de Fuca Ridge flanks. Geochem., Geophys., Geosyst., 9(9):Q09006. doi:10.1029/ 2008GC002085

Orcutt, B.N., Bowman, D., Inderbitzen, K., Turner, A., Fisher, A.T., Peart, L., and the IODP Expedition 327 Shipboard Party, submitted. The "Adopt-a-Microbe" project: art and storytelling in web-based interactive biology and Earth science education connected with scientific ocean drilling. Sci Scope.

Parsons, B., and Sclater, J.G., 1977. An analysis of the variation of ocean floor bathymetry and heat flow with age. J. Geophys. Res., [Solid Earth], 82(5):803-827. doi:10.1029/JB082i005p00803

Peacock, S.M., and Wang, K., 1999. Seismic consequences of warm versus cool subduction metamorphism: examples from southwest and northeast Japan. Science, 286(5441):937-939. doi:10.1126/science.286.5441.937

Rosenberger, A., Davis, E.E., and Villinger, H., 2000. Data report: hydrocell-95 and -96 single-channel seismic data on the eastern Juan de Fuca Ridge Flank. In Fisher, A., Davis, E.E., and Escutia, C. (Eds.), Proc. ODP, Sci. Results, 
168: College Station, TX (Ocean Drilling Program), 919. doi:10.2973/odp.proc.sr.168.021.2000

Ryan, W.B.F., Carbotte, S.M., Coplan, J.O., O'Hara, S., Melkonian, A., Arko, R., Weissel, R.A., Ferrini, V., Goodwillie, A., Nitsche, F., Bonczkowski, J., and Zemsky, R., 2009. Global multi-resolution topography synthesis. Geochem., Geophys., Geosyst., 10(3):Q03014. doi:10.1029/2008GC002332

Stein, J.S., and Fisher, A.T., 2003. Observations and models of lateral hydrothermal circulation on a young ridge flank: numerical evaluation of thermal and chemical constraints. Geochem., Geophys., Geosyst., 4(3):1026. doi:10.1029/2002GC000415

Von Herzen, R.P., 2004. Geothermal evidence for continuing hydrothermal circulation in older (>60 Ma) ocean crust. In Davis, E.E., and Elderfield, H. (Eds.) Hydrogeology of the Oceanic Lithosphere: Cambridge (Cambridge Univ. Press), 414-450.

Walker, B.D., McCarthy, M.D., Fisher, A.T., and Guilderson, T.P., 2007. Dissolved inorganic carbon isotopic composition of low-temperature axial and ridge-flank hydrothermal fluids of the Juan de Fuca Ridge. Mar. Chem., 108(1-2):123-136. doi:10.1016/ j.marchem.2007.11.002

Wheat, C.G., Elderfield, H., Mottl, M.J., and Monnin, C., 2000. Chemical composition of basement fluids within an oceanic ridge flank: implications for along-strike and across-strike hydrothermal circulation. J. Geophys. Res., [Solid Earth], 105(B6):13437-13447. doi:10.1029/ 2000JB900070

Wheat, C.G., McManus, J., Mottl, M.J., and Giambalvo, E. 2003a. Oceanic phosphorus imbalance: the magnitude of the ridge-flank hydrothermal sink. Geophys. Res. Lett., 30(17):1895. doi:10.1029/2003GL017318
Wheat, C.G., Jannasch, H.W., Kastner, M., Plant, J.N., and DeCarlo, E.H., 2003b. Seawater transport and reaction in upper oceanic basaltic basement: chemical data from continuous monitoring of sealed boreholes in a ridge flank environment. Earth Planet. Sci. Lett., 216(4):549564. doi:10.1016/S0012-821X(03)00549-1

Wheat, C.G., and Mottl, M.J., 1994. Hydrothermal circulation, Juan de Fuca Ridge eastern flank: factors controlling basement water composition. J. Geophys. Res., [Solid Earth], 99(B2):3067-3080. doi:10.1029/93JB01612

Wheat, C.G., Mottl, M.J., Fisher, A.T., Kadko, D., Davis, E.E., and Baker, E., 2004. Heat flow through a basaltic outcrop on a sedimented young ridge flank. Geochem., Geophys., Geosyst., 5(12):Q12006. doi:10.1029/ 2004GC000700

Zühlsdorff, L., Hutnak, M., Fisher, A.T., Spiess, V., Davis, E.E., Nedimovic, M., Carbotte, S., Villinger, H., and Becker, K., 2005. Site surveys related to IODP Expedition 301: ImageFlux (SO149) and RetroFlux (TN116) expeditions and earlier studies. In Fisher, A.T., Urabe, T., Klaus, A., and the Expedition 301 Scientists, Proc. IODP, 301: College Station, TX (Integrated Ocean Drilling Program Management International, Inc.). doi:10.2204/ iodp.proc.301.102.2005

Zühlsdorff, L., and Spiess, V., 2006. Sedimentation patterns, folding, and fluid upflow above a buried basement ridge: results from 2-D and 3-D seismic surveys at the eastern Juan de Fuca Ridge flank. J. Geophys. Res., [Solid Earth], 111(B8):B08103. doi:10.1029/ 2004JB003227

Publication: 5 September 2011 MS 327-101 
Figure F1. Index map for Integrated Ocean Drilling Program (IODP) Expedition 327 and small inset showing work area. Site U1362 is located at the eastern end of the Ocean Drilling Program (ODP) Leg 168 drilling transect (Davis, Fisher, Firth, et al., 1997), whereas Site U1363 is located adjacent to a large basement outcrop $\sim 52 \mathrm{~km}$ to the south-southwest, a hypothesized location of ridge-flank hydrothermal recharge (Wheat et al., 2000; Fisher et al., 2003; Hutnak et al., 2006). Yellow box indicates location of Figure F2. Map generated using GeoMapApp (www.geomapapp.org/) and the global multiresolution topography synthesis (Ryan et al., 2009).

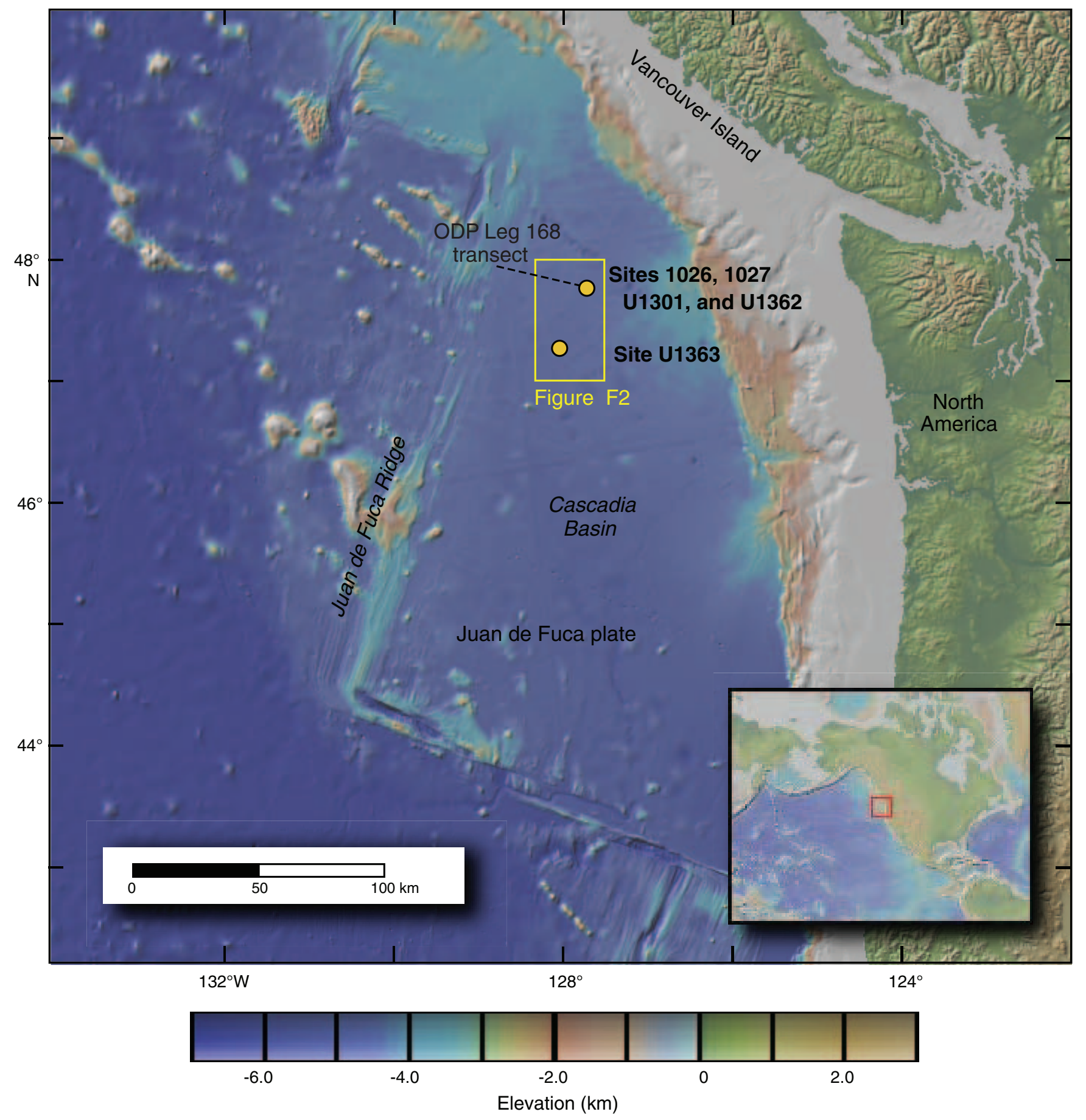


Figure F2. Regional bathymetric map showing locations of Integrated Ocean Drilling Program (IODP) Expedition 327 drill sites and basement outcrops (modified from Zühlsdorff et al., 2005). Thermal and chemical data suggest hydrothermal fluids recharge at Grizzly Bare outcrop and flow north-northeast (white arrow). ODP = Ocean Drilling Program.

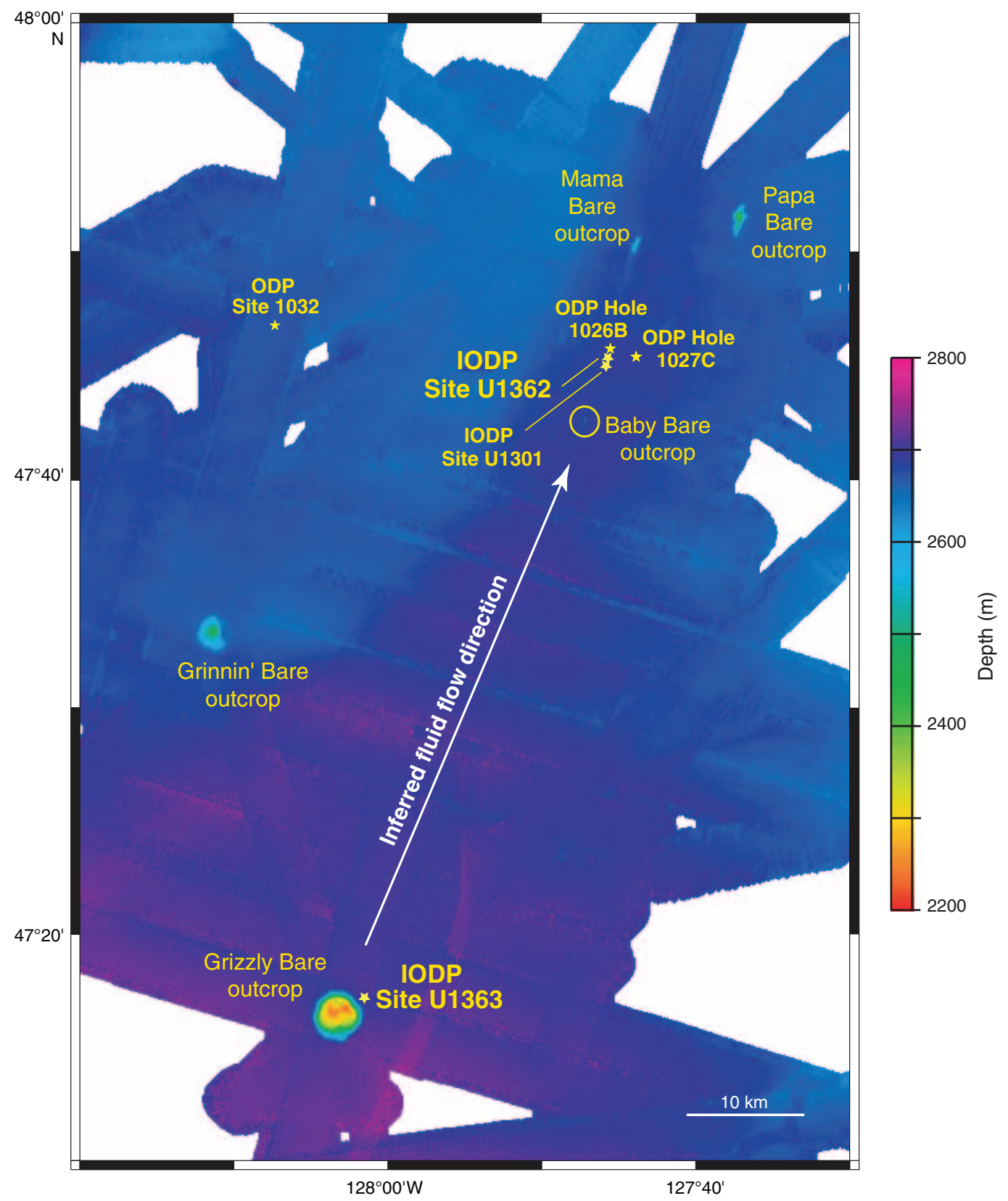


Figure F3. Three-dimensional perspective views of basement relief around Expedition 327 drill sites. Bathymetry based on digitization of seismic lines across work areas (data from Rosenberger et al., 2000; Zühlsdorff et al., 2005; Hutnak et al., 2006). Relief is shown as two-way traveltime, with no conversion to sediment thickness or depth. A. Basement relief around Sites 1026, 1027, U1301, and U1362, contoured to maintain continuity along-strike ( N20E) to highlight steeply dipping normal faults to west of drill sites. B. Basement relief around Site U1363, adjacent to Grizzly Bare outcrop. Detailed hole locations at Site U1363 are shown in "Operations" and "Background and objectives" in the "Site U1363" chapter.
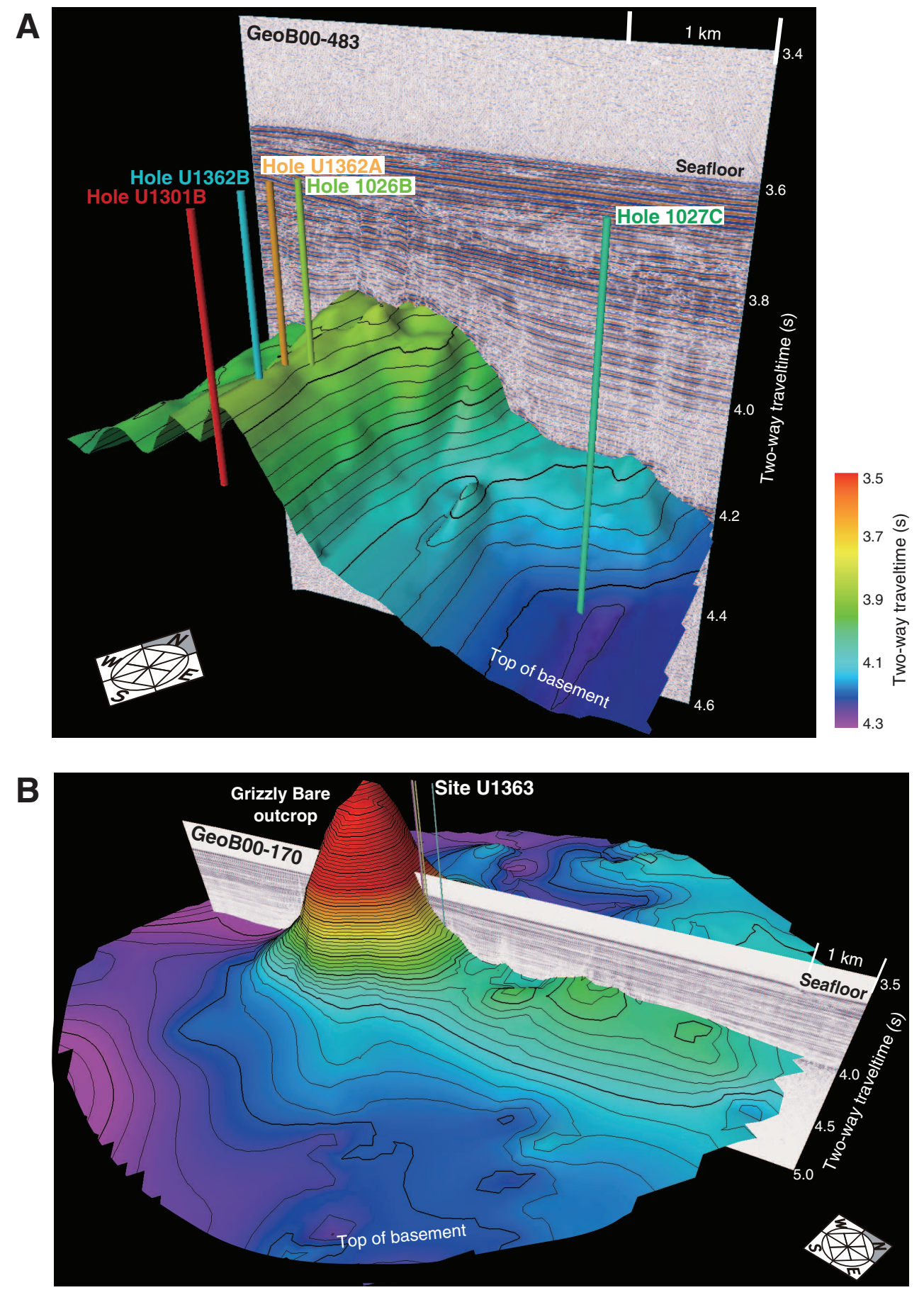
Figure F4. Seafloor heat flow data and numerical modeling results of single-outcrop and outcrop-to-outcrop hydrothermal circulation (modified from Hutnak et al., 2006). A. Heat flow measured within $7 \mathrm{~km}$ of Baby Bare outcrop, projected along a single profile. B. Fluid flow vectors through upper basement and across seafloor, simulating single-outcrop circulation. Radial fluid flow results in heat flow pattern shown in A (dashed lines). C. Vertical temperature profiles from two-dimensional simulations of self-sustaining fluid and heat flow from Grizzly Bare to Baby Bare outcrops. Low temperatures are maintained in the recharge conduit (through Grizzly Bare; blue lines and symbols), whereas various temperatures are maintained through the discharge conduit (through Baby Bare; red lines and symbols), with the upflow temperature being dependent on the permeability of upper basement. When permeability is too high, basement is cooled by rapidly flowing fluids. When permeability is too low, basement becomes warmer. A match to the observed regional upper basement temperature of $60^{\circ}-65^{\circ} \mathrm{C}$ is achieved with a basement permeability of $\sim 10^{-11} \mathrm{~m}^{2}$.
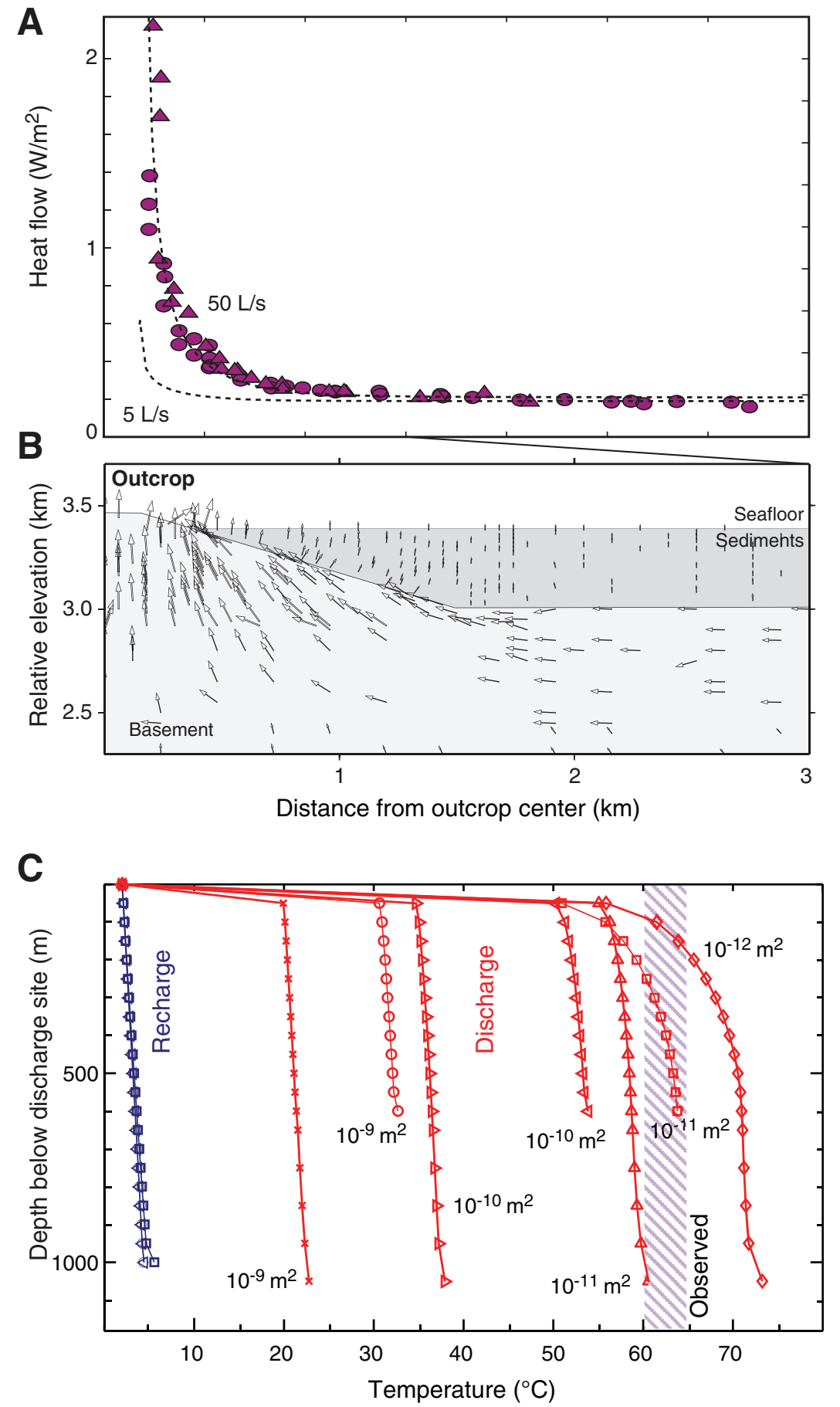
Figure F5. A. Cross-hole response in Hole 1027C CORK to long-term flow into Hole U1301B, $2.4 \mathrm{~km}$ away (Fisher et al., 2008). Pressure record from Hole 1027C (blue line), corrected for tidal loading and other instantaneous responses, indicates basement permeability shown, a range lower than that indicated by packer tests or larger scale methods. B. Geometry of cross-hole pressure response. Hole 1027C is oriented along a trend oblique to the structural strike of basement. The direction of greatest permeability is hypothesized to be along structural strike, N20E (blue dashed arrow), whereas cross-hole response direction is N70E (red dashed arrow), an azimuthal angle of $50^{\circ}$. C. Calculated effective permeability as a function of testing angle in an anisotropic medium. The full cross-hole experiment, with monitoring wells at different angles and depths, will test for permeability anisotropy. IODP = Integrated Ocean Drilling Program.

A

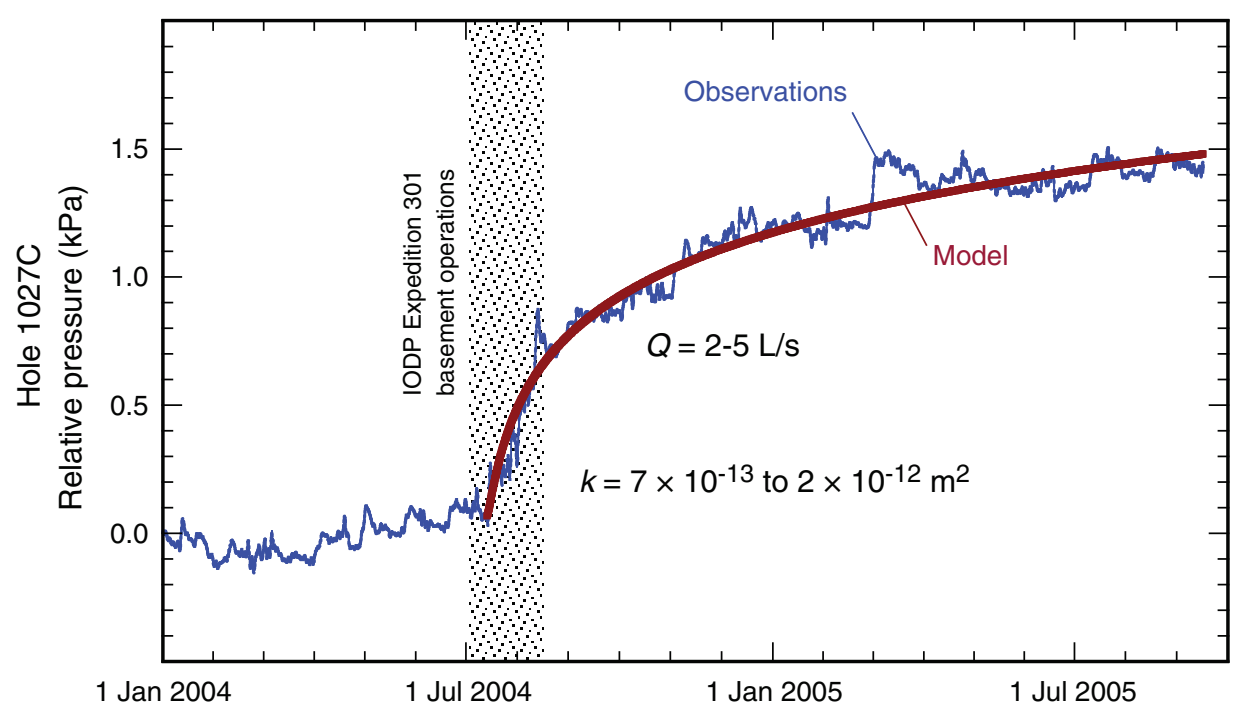

B

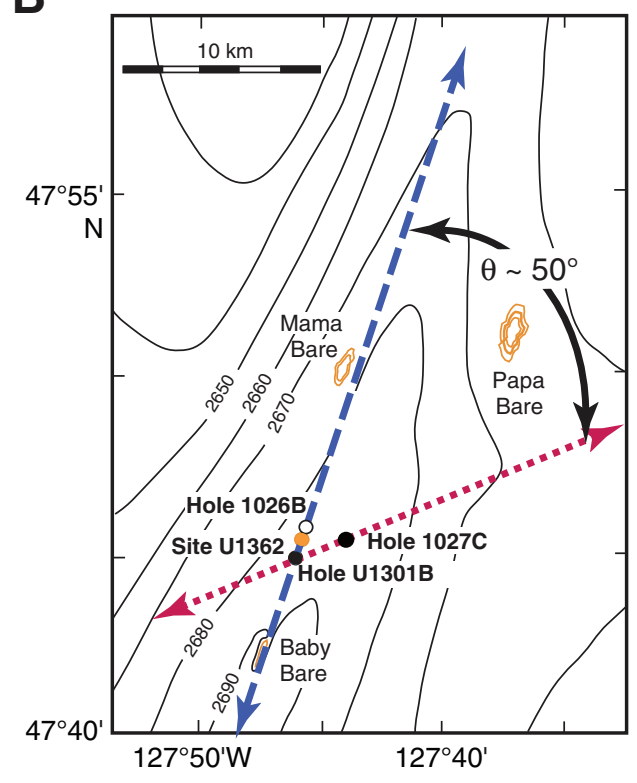

C

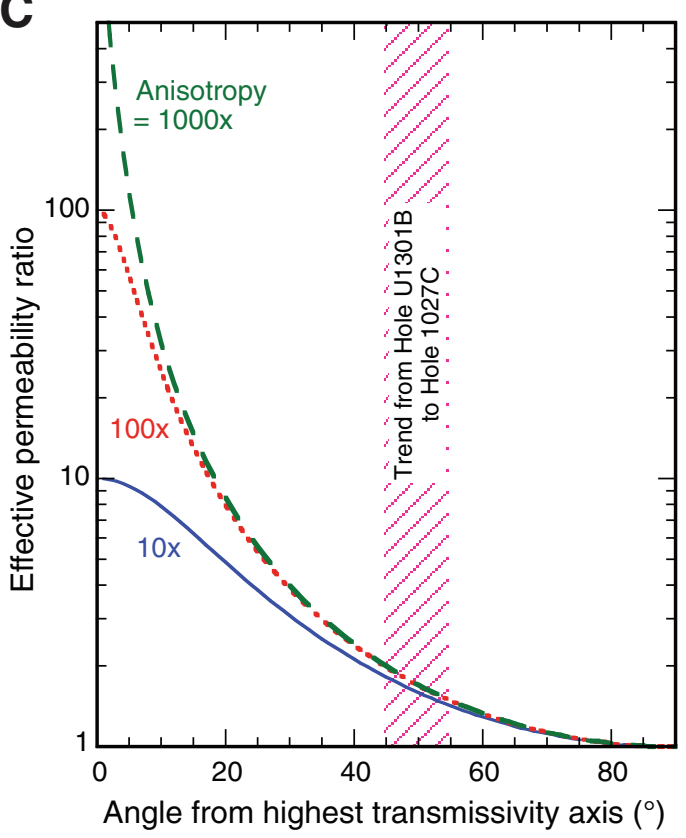


Figure F6. Composite of the global data set of borehole permeability estimates from packer testing and other select methods. Data from Hole U1301B are broadly consistent with the global data set, but single-hole packer results suggest higher permeability than does the cross-hole response. This is surprising because testing of large rock volumes tends to result in higher permeability estimates. Also shown is the range of values generally determined on the basis of idealized crustal response to tidal loading and seismic events and using numerical models of coupled fluid and heat flow.

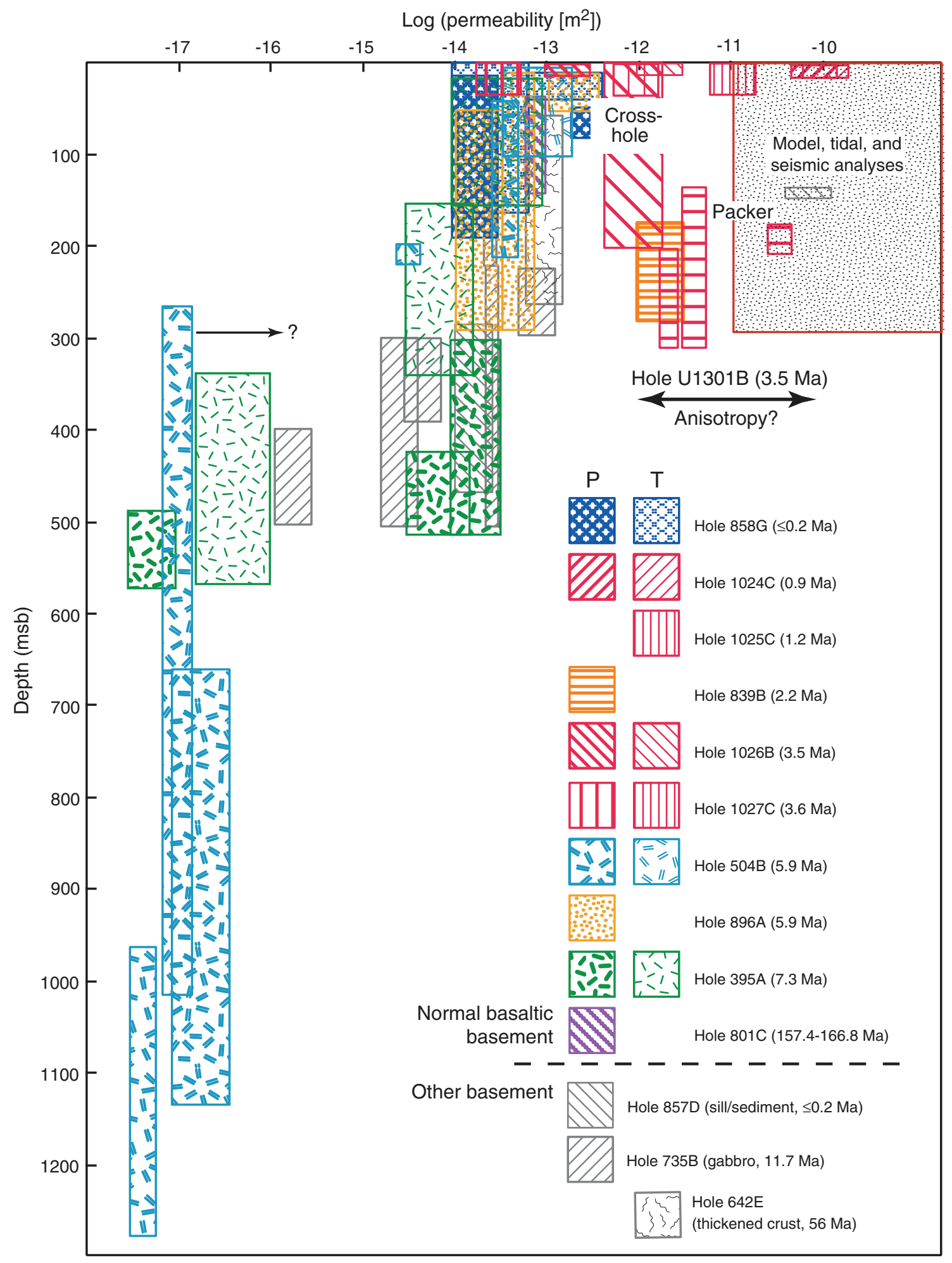


Figure F7. Schematic of Hole U1362A seafloor installation after completion of subseafloor drilling, coring, and casing operations but prior to installation of a long-term subseafloor borehole observatory (CORK). The Hole U1362A CORK is illustrated schematically in Figure F13.

Hole U1362A

Seafloor installation

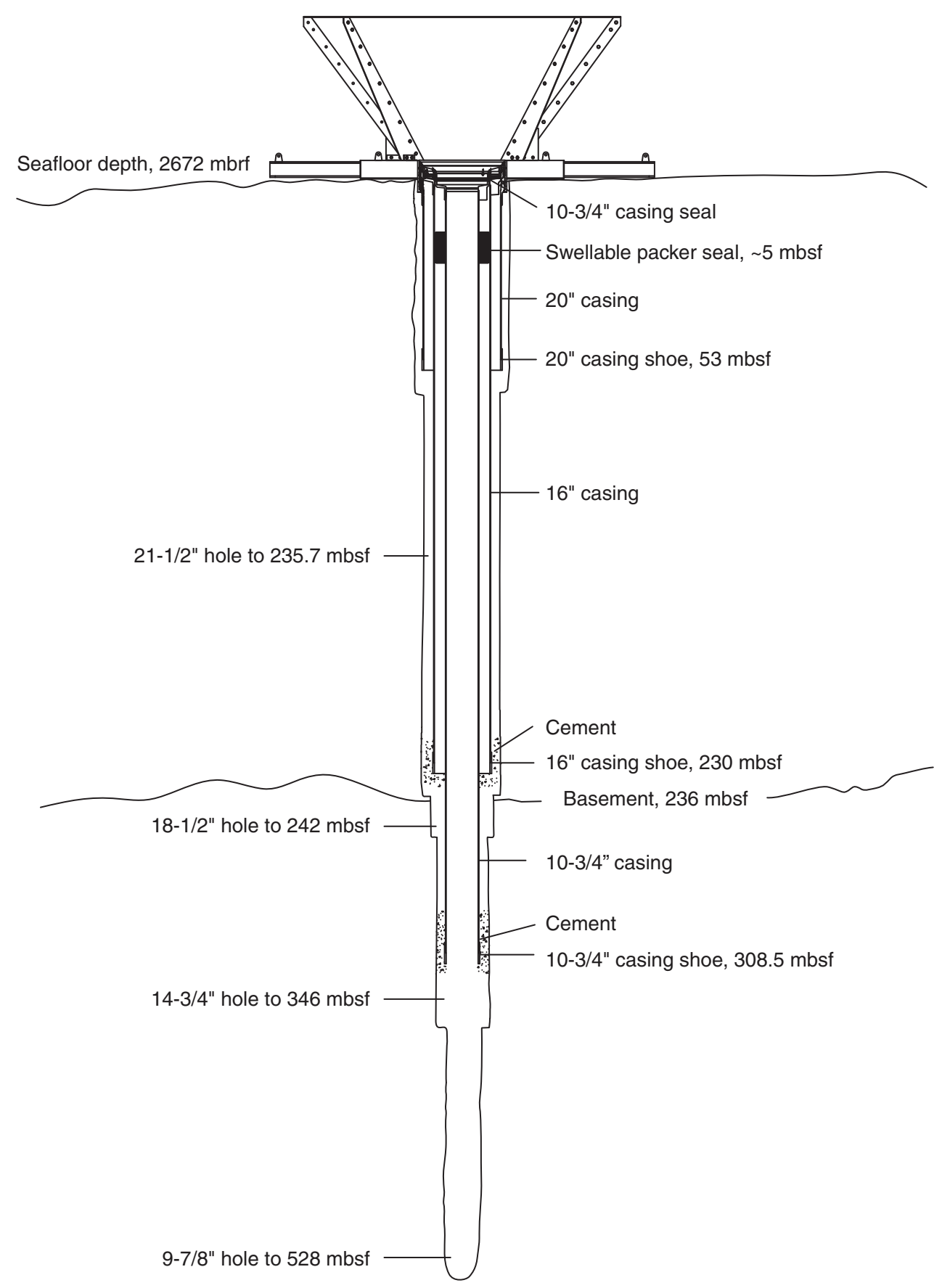


Figure F8. Schematic of Hole U1362B seafloor installation after completion of subseafloor drilling and casing operations but prior to installation of a long-term subseafloor borehole observatory (CORK). The Hole U1362B CORK is illustrated schematically in Figure F13.

Hole U1362B

Seafloor installation

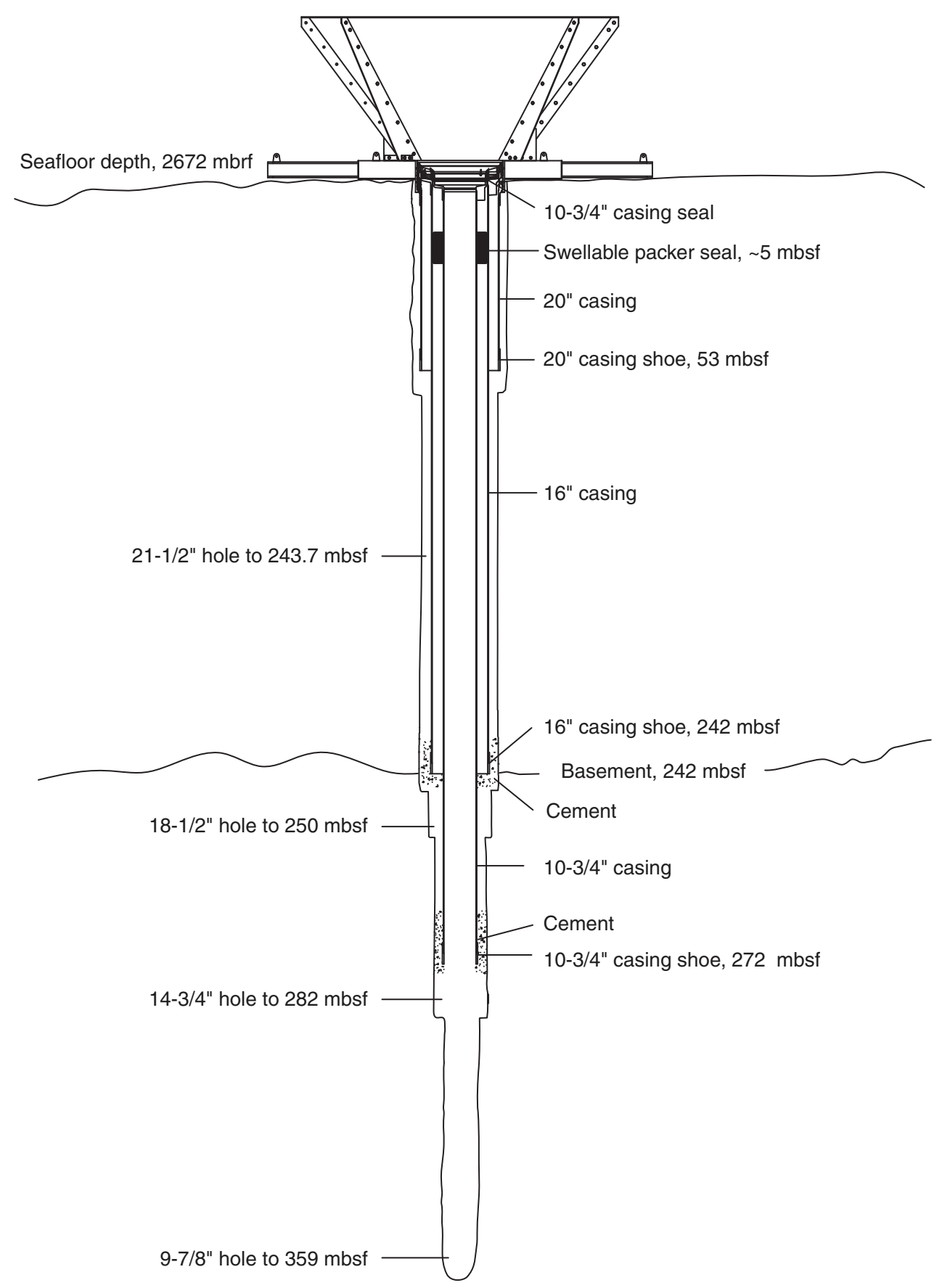


Figure F9. Calculated tides at the Expedition 327 drill sites. A. Tides for duration of expedition. B. Tides for a two-day period, including period when $>100 \%$ of a hard rock core was recovered. When the ship moved downward during a falling tide, penetration sometimes exceeded the relative motion of the bit with respect to the rig floor.

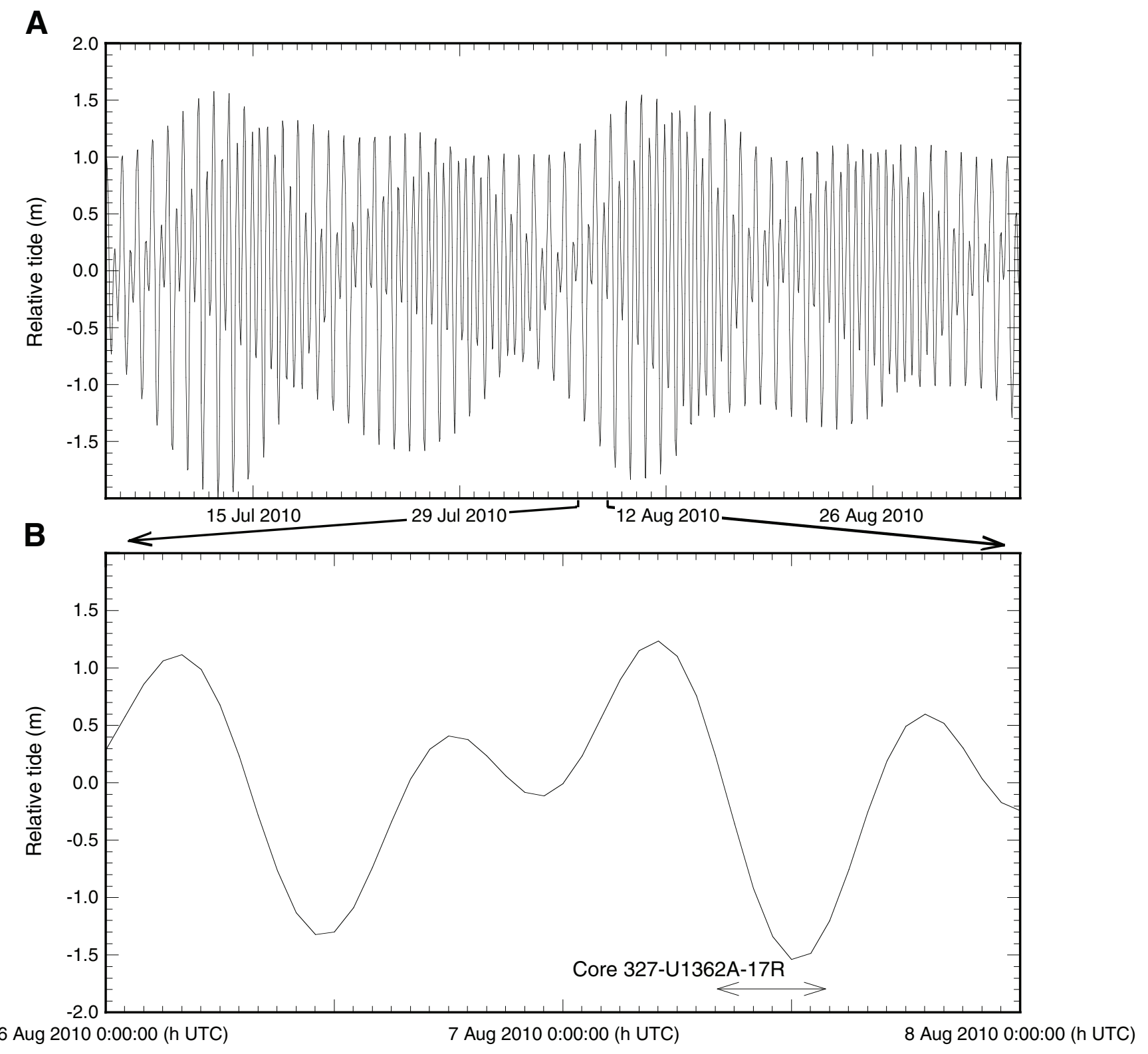


Figure F10. Composite diagram showing basement recovery, lithology, hole diameter, and bulk density of logging and discrete measurements from Holes U1362A and U1301B (Expedition 301), hung on a common datum of top of basement. Primary lithologies were described using different terminology during Expeditions 301 and 327, but they are equivalent, as indicated by color and pattern. Hole diameter was determined by mechanical caliper on the lithodensity log. The upper part of Hole U1362A (above the lithologic column) was drilled with a 143/4 inch tricone bit, whereas other hole sections shown were drilled with 9 inch bits. CORK = subseafloor borehole observatory.
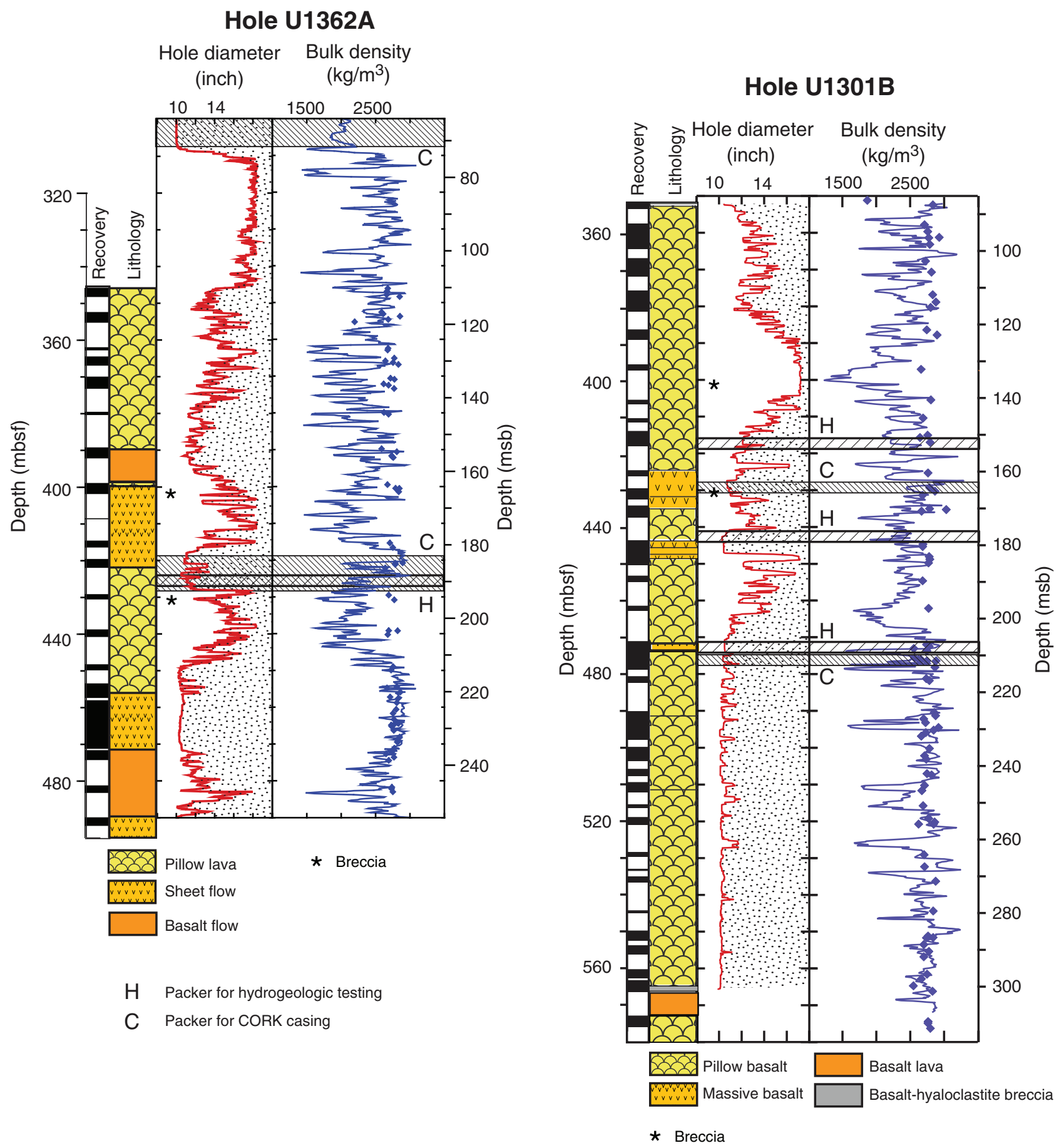
Figure F11. Comparison of borehole caliper width and penetration rates for Holes U1362A, U1362B, and U1301B. Some continuity of distinct basement layers is apparent between the holes, which are separated by 300-500 $\mathrm{m}$ in an along-strike direction (Fig. F3).

NNE
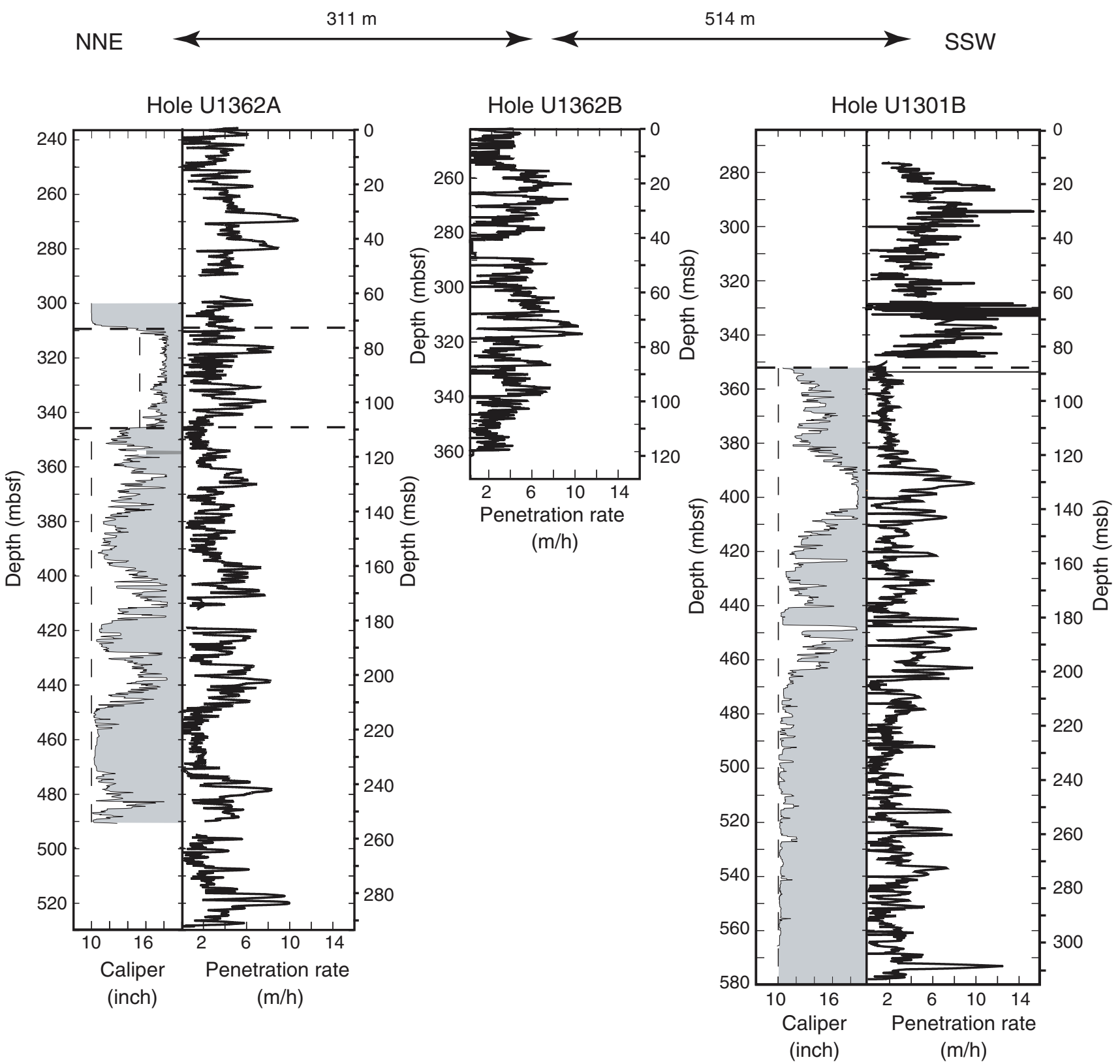
Figure F12. Plots showing schematic variations in pumping rates and tracer concentrations during $24 \mathrm{~h}$ pumping experiment. Actual values will be calculated postcruise using detailed records of pumping rates, gas and fluid pressure, and injectate chemistry. A. Flow rate. The mud pump was run at a constant rate of 20 strokes per minute $(\sim 7 \mathrm{~L} / \mathrm{s})$. The cement pump added injectate four times during the experiment, briefly increasing total injection rate into the formation. $\mathrm{B}$. Injectate salinity and $\mathrm{SF}_{6}$ concentration. $\mathrm{SF}_{6}$ was added to the injectate using a regulator and valve manifold connected to the standpipe upstream of the mud pump. A differential pressure of $\sim 80$ psi was used to inject the gas at a constant concentration, except when flow from the cement pump was added, briefly reducing the $\mathrm{SF}_{6}$ concentration (but having no influence on the mass rate of $\mathrm{SF}_{6}$ injection). Seawater was the primary injectate, except for two $1 \mathrm{~h}$ periods when freshwater was injected and two other times when Cs, Er, and Ho salts were added, temporarily increasing injectate salinity. C. Approximate concentrations of Cs, Er, and Ho salts and relative concentrations of fluorescent microspheres and bacteria.

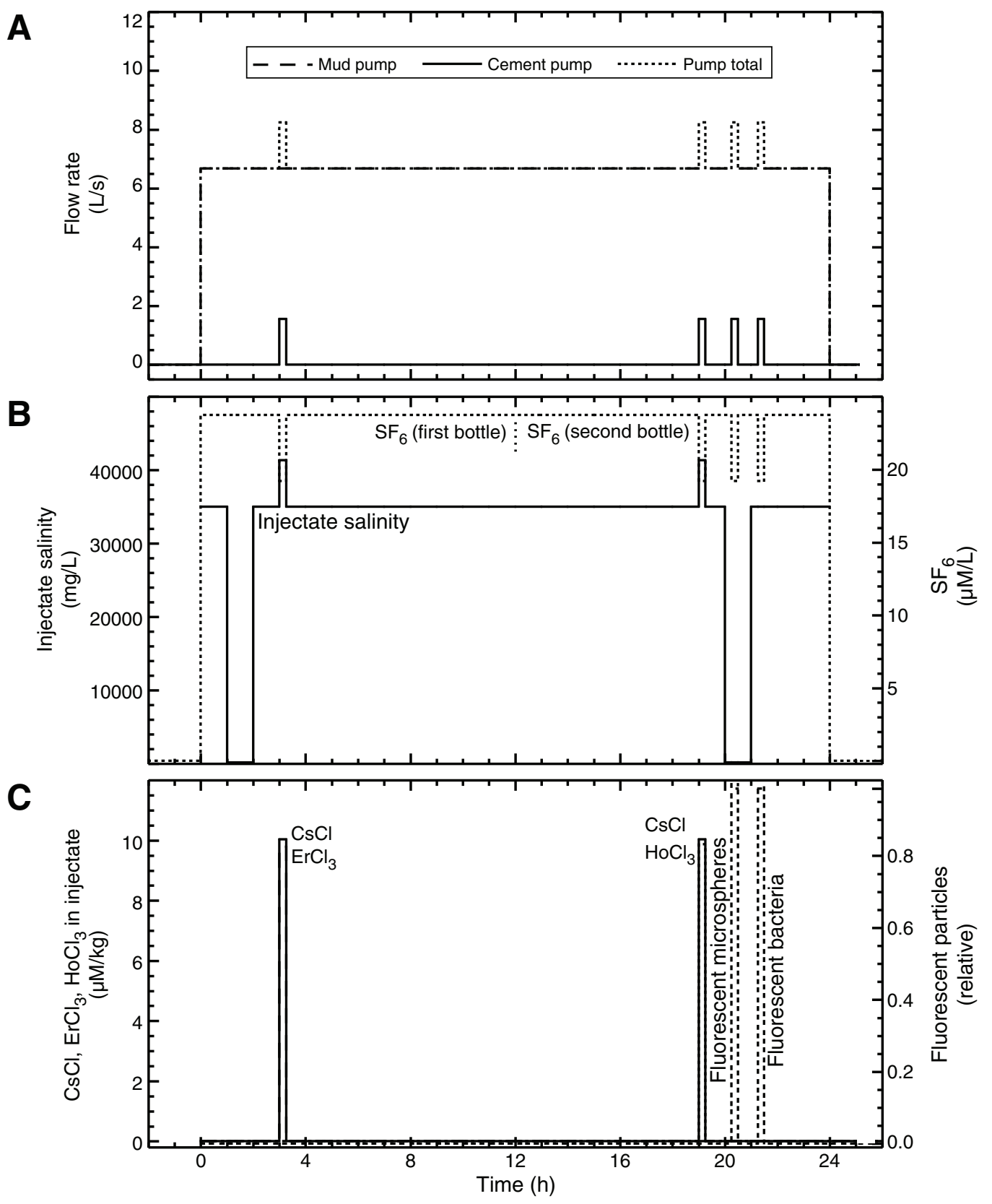


Figure F13. Schematic diagrams showing subseafloor borehole observatory (CORK) completions in Holes U1362A and U1362B. Figures are exaggerated horizontally but are drawn vertically to scale and hung on a common datum at the sediment/basalt interface. Each CORK comprises four concentric casing strings, a casing seal and swellable casing packer near the seafloor, and one or two sets of inflatable and swellable packers at depth. Both CORKs use the new "L-CORK" design, with a lateral casing section extending from the inner 41/2 inch CORK casing to a free-flow ball valve at the wellhead. Both CORKs have perforated and coated 51/2 inch casing and drill collars, into which numerous OsmoSamplers and microbiological growth experiments were placed. Pressure loggers and gauges were installed in the wellhead and connected to monitored intervals at depth with $1 / 4$ inch tubing and miniscreens. Fluid and microbiological sampling will be accomplished from the wellhead using dedicated lines and miniscreens at depth.

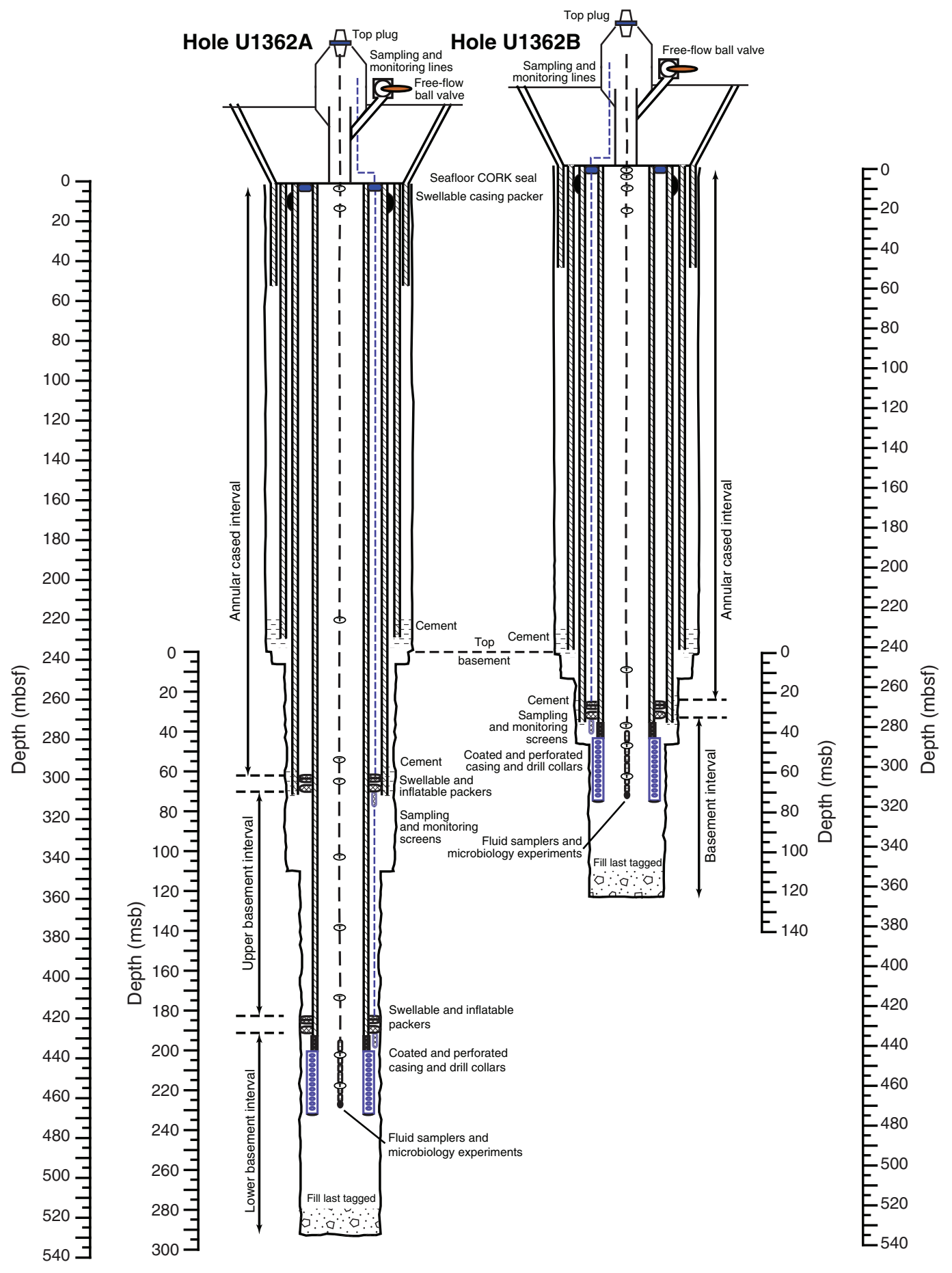


Figure F14. Sediment recovery and lithostratigraphy, Site U1363. A bathymetric map with Site U1363 hole locations is also shown.

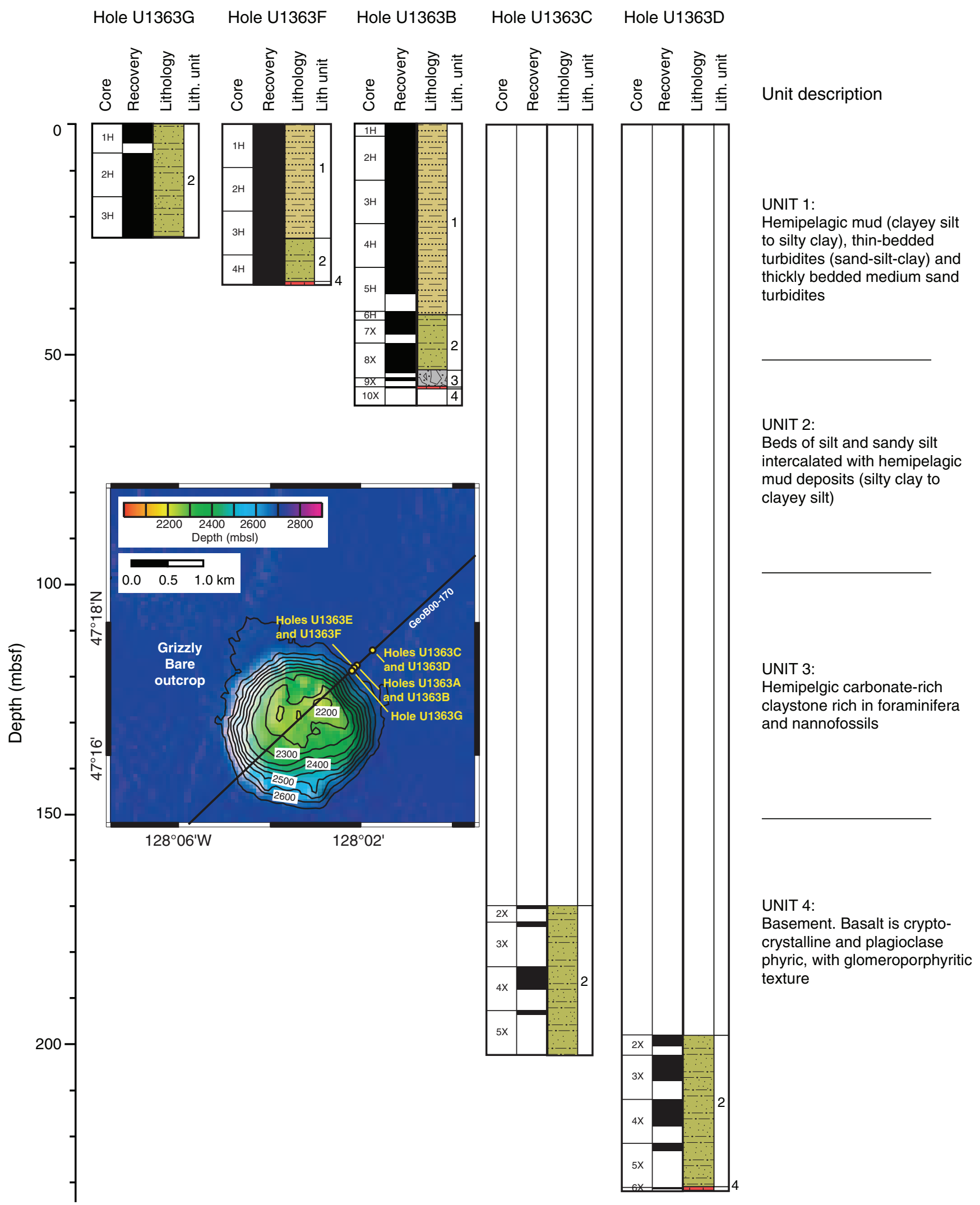


Figure F15. Selected education, outreach, and communications (EOC) projects during Expedition 327. A. Screenshot of a staff-maintained blog. B. Screenshot of the Adopt-A-Microbe website, which includes educational materials, activities, stories, art work, and other information. C. Screenshot of Ocean Gazing podcast website. D. Metrics showing site visits on a daily basis for www.joidesresolution.org/. Traffic at this site increased by 40\% during Expedition 327.

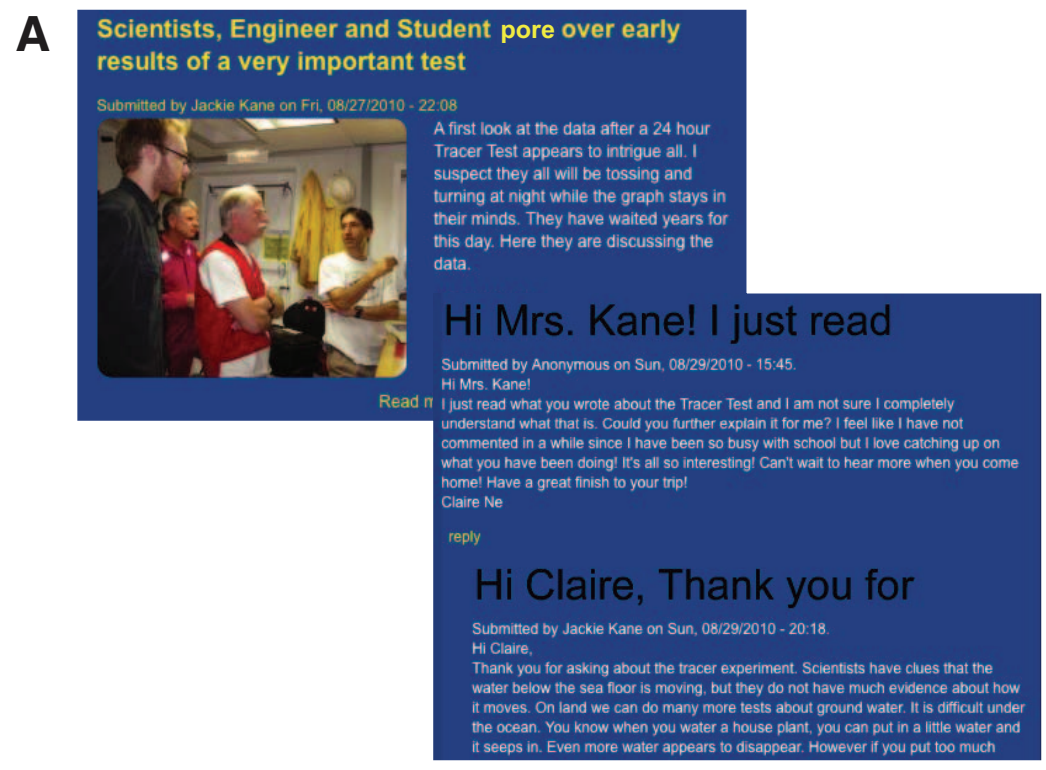

B

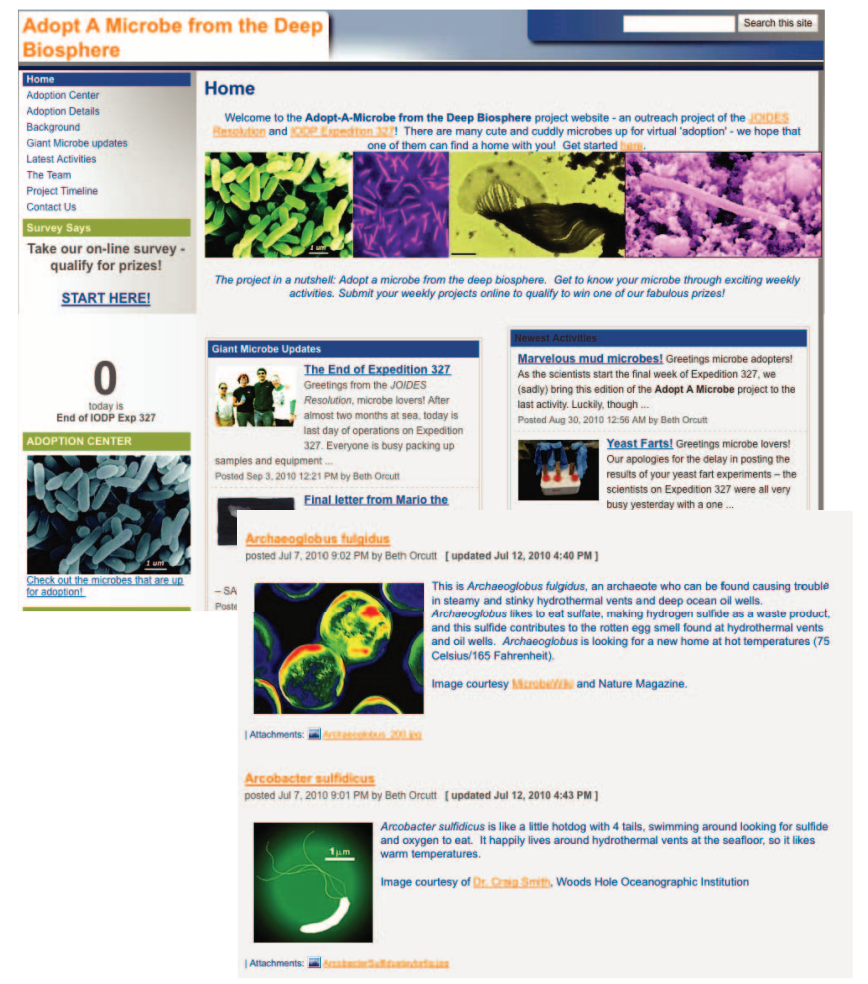

C

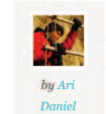

Scientists, teachers and artists, oh, my! tuly 23. 2010 in Oecan Gemino Podenst by Ari Damicl Shomin

Stephanie Keske Stephanie Keske
does computer visualization
work, and is starting a graduate program this fal at Texas A8M University, She told me, "Just living on a ship, I think.... you know, Itry to be outside as much as I can so jus being trapped on a floating hunk of metal is maybe going to be little dificult. I don't know. Tve never leave if tor 2 months solid: northeast Pacific onboard an and six other educators ans artists

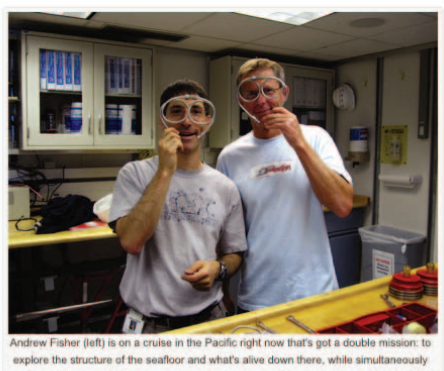
from the US and France are working with the science team to do unprecedenteded ourreach. Have a listen $\hookrightarrow>$

Download the audio.

D JOIDES Resolution , Users

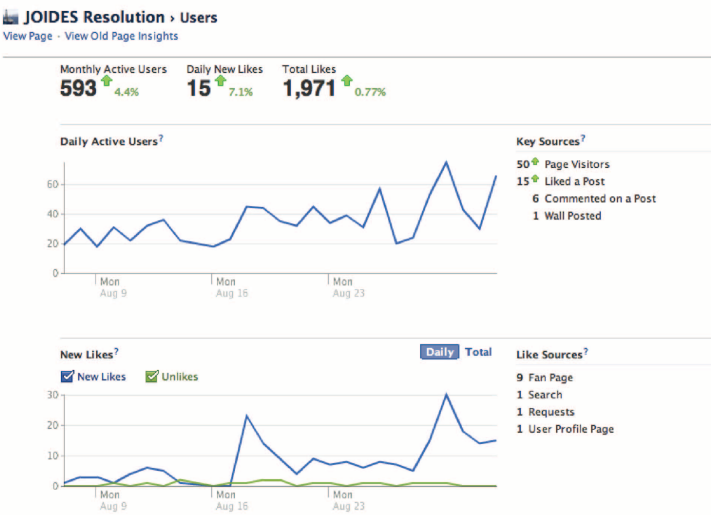


Table T1. Expedition 327 operations summary. (See table notes.) (Continued on next page.)

\begin{tabular}{|c|c|c|c|c|c|c|}
\hline \multirow[b]{2}{*}{ Operational task } & \multicolumn{2}{|c|}{ Start } & \multicolumn{2}{|c|}{ End } & \multicolumn{2}{|c|}{ Task time } \\
\hline & $\begin{array}{l}\text { Date } \\
(2010)\end{array}$ & $\begin{array}{l}\text { Local ship } \\
\text { time (h) }\end{array}$ & $\begin{array}{l}\text { Date } \\
(2010)\end{array}$ & $\begin{array}{l}\text { Local ship } \\
\text { time }(\mathrm{h})\end{array}$ & $\mathrm{h}$ & Days \\
\hline Depart Victoria, British Columbia (Canada), and transit $196 \mathrm{nmi}$ to Site U1362 & 9 Jul & 1215 & $10 \mathrm{Jul}$ & 0815 & 20.00 & 0.8 \\
\hline \multicolumn{7}{|l|}{ Site U1362 (SR-2) } \\
\hline Jet-in test in Hole U1362B & $10 \mathrm{Jul}$ & 0815 & $11 \mathrm{Jul}$ & 1130 & 27.25 & 1.1 \\
\hline Jet-in test in Hole U1362A & $11 \mathrm{Jul}$ & 1130 & $12 \mathrm{Jul}$ & 0815 & 20.75 & 0.9 \\
\hline \multicolumn{7}{|l|}{ Hole U1362A (SR-2A) Stage 1} \\
\hline Install reentry cone and 20 inch casing & $12 \mathrm{Jul}$ & 0815 & $13 \mathrm{Jul}$ & 1800 & & \\
\hline Make up BHA with underreamer cutters set to $21-1 / 2$ inch diameter; run in hole & $13 \mathrm{Jul}$ & 1800 & $14 \mathrm{Jul}$ & 0345 & & \\
\hline Drill $21-1 / 2$ inch hole for 16 inch casing to $235.7 \mathrm{mbsf}$ ( $18-1 / 2$ inch hole to $242 \mathrm{mbsf})^{*}$ & $13 \mathrm{Jul}$ & 1800 & $15 \mathrm{Jul}$ & 0915 & & \\
\hline Install 16 inch casing & $15 \mathrm{Jul}$ & 0915 & $15 \mathrm{Jul}$ & 2315 & & \\
\hline Cement 16 inch casing shoe and annulus & $15 \mathrm{Jul}$ & 2315 & $16 \mathrm{Jul}$ & 0345 & & \\
\hline Pull out of hole & 16 Jul & 0345 & $16 \mathrm{Jul}$ & 0930 & 97.25 & 4.1 \\
\hline \multicolumn{7}{|l|}{ Hole U1362B (SR-2B) Stage 1} \\
\hline Install reentry cone and 20 inch casing & $16 \mathrm{Jul}$ & 0930 & $17 \mathrm{Jul}$ & 1630 & & \\
\hline Make up BHA with underreamer cutters set to $21-1 / 2$ inch diameter; run in hole & $17 \mathrm{Jul}$ & 1630 & $18 \mathrm{Jul}$ & 0145 & & \\
\hline Drill $21-1 / 2$ inch hole for 16 inch casing to $243.7 \mathrm{mbsf}$ (18-1/2 inch hole to $250 \mathrm{mbsf})^{*}$ & $18 \mathrm{Jul}$ & 0145 & $19 \mathrm{Jul}$ & 0630 & & \\
\hline Install 16 inch casing & 19 Jul & 0630 & 19 Jul & 1900 & & \\
\hline Cement 16 inch casing shoe and annulus & $19 \mathrm{Jul}$ & 1900 & 19 Jul & 2015 & & \\
\hline Pull out of hole & 19 Jul & 2015 & $20 \mathrm{Jul}$ & 0330 & 90.00 & 3.8 \\
\hline \multicolumn{7}{|l|}{ Hole U1362A (SR-2A) Stage 2} \\
\hline Make up 14-3/4 inch drilling assembly; run in hole & $20 \mathrm{Jul}$ & 0330 & $20 \mathrm{Jul}$ & 1645 & & \\
\hline Drill out cement & $20 \mathrm{Jul}$ & 1645 & 20 Jul & 2400 & & \\
\hline Drill $14-3 / 4$ inch hole for $10-3 / 4$ inch casing & $20 \mathrm{Jul}$ & 2400 & $24 \mathrm{Jul}$ & 0340 & & \\
\hline Install $10-3 / 4$ inch casing & $24 \mathrm{Jul}$ & 0340 & $26 \mathrm{Jul}$ & 0530 & & \\
\hline Cement $10-3 / 4$ inch casing & $26 \mathrm{Jul}$ & 0530 & $26 \mathrm{Jul}$ & 0730 & & \\
\hline Pull out of hole & $26 \mathrm{Jul}$ & 0730 & $26 \mathrm{Jul}$ & 1245 & 153.25 & 6.4 \\
\hline \multicolumn{7}{|l|}{ Hole U1362B (SR-2B) Stage 2} \\
\hline Make up 14-3/4 inch drilling assembly; run in hole & $26 \mathrm{Jul}$ & 1245 & $26 \mathrm{Jul}$ & 2145 & & \\
\hline Drill out cement & $26 \mathrm{Jul}$ & 2145 & $27 \mathrm{Jul}$ & 0100 & & \\
\hline Drill $14-3 / 4$ inch hole for $10-3 / 4$ inch casing & $27 \mathrm{Jul}$ & 0100 & 28 Jul & 0215 & & \\
\hline Install 10-3/4 inch casing & $28 \mathrm{Jul}$ & 0215 & $28 \mathrm{Jul}$ & 1330 & & \\
\hline Cement $10-3 / 4$ inch casing & $28 \mathrm{Jul}$ & 1330 & $28 \mathrm{Jul}$ & 1515 & & \\
\hline Pull out of hole & $28 \mathrm{Jul}$ & 1515 & $28 \mathrm{Jul}$ & 2030 & & \\
\hline Make up 9-7/8 inch drilling assembly; run in hole & $28 \mathrm{Jul}$ & 2030 & $29 \mathrm{Jul}$ & 0500 & & \\
\hline Drill out cement to $10 \mathrm{~m}$ above casing shoe & $29 \mathrm{Jul}$ & 0500 & 29 Jul & 1815 & & \\
\hline Pull out of seafloor & 29 Jul & 1815 & 29 Jul & 1900 & 78.25 & 3.3 \\
\hline \multicolumn{7}{|l|}{ Hole U1362A (SR-2A) Stage 3} \\
\hline Run in hole with $9-7 / 8$ inch drilling assembly & $29 \mathrm{Jul}$ & 1900 & $30 \mathrm{Jul}$ & 0230 & & \\
\hline Drill out cement & $30 \mathrm{Jul}$ & 0230 & $30 \mathrm{Jul}$ & 0730 & & \\
\hline Condition hole & 30 Jul & 0730 & $31 \mathrm{Jul}$ & 0900 & & \\
\hline Make up 9-7/8 inch RCB assembly; run in hole & $31 \mathrm{Jul}$ & 0900 & $31 \mathrm{jul}$ & 2215 & & \\
\hline RCB core from 346 to $496 \mathrm{mbsf}$ & 31 Jul & 2215 & 9 Aug & 1400 & & \\
\hline Make up 9-7/8 inch drilling assembly; run in hole & 9 Aug & 1400 & 9 Aug & 2400 & & \\
\hline Drill 9-7/8 inch hole to $528 \mathrm{mbsf}$; stand by and conduct open hole depth check & 9 Aug & 2400 & 11 Aug & 1845 & & \\
\hline Make up wireline logging/packer BHA; run in hole & 11 Aug & 1845 & 12 Aug & 0330 & & \\
\hline Rig up Schlumberger line and make up logging tool string & 12 Aug & 0330 & 12 Aug & 0545 & & \\
\hline Wireline log with three passes & 12 Aug & 0545 & 12 Aug & 1645 & & \\
\hline Conduct open hole depth check & 12 Aug & 1645 & 12 Aug & 1900 & & \\
\hline Conduct packer flow test & 12 Aug & 1900 & 13 Aug & 1800 & & \\
\hline Make up CORK assembly with 4-1/2 inch casing, packers, miniscreens, and umbilicals & 13 Aug & 1800 & 15 Aug & 1630 & & \\
\hline Deploy OsmoSamplers, sinker bar, and Spectra rope with thermistors & 15 Aug & 1630 & 16 Aug & 0600 & & \\
\hline Install CORK and pressure up packers & 16 Aug & 0600 & 16 Aug & 1600 & & \\
\hline Deploy ROV platform and release CORK head & 16 Aug & 1600 & 17 Aug & 0600 & & \\
\hline Pull out of hole & 17 Aug & 0600 & 17 Aug & 1045 & 447.75 & 18.7 \\
\hline \multicolumn{7}{|l|}{ Hole U1301B } \\
\hline Run in hole with CORK recovery tool & 17 Aug & 1045 & 17 Aug & 1615 & & \\
\hline Engage CORK head and recover partial instrument string & 17 Aug & 1615 & 17 Aug & 1945 & & \\
\hline Run in hole for depth check and temperature profile & 17 Aug & 1945 & 18 Aug & 0145 & & \\
\hline Deploy replacement instrument string & 18 Aug & 0145 & 18 Aug & 0530 & 18.75 & 0.8 \\
\hline \multicolumn{7}{|l|}{ Hole $1027 \mathrm{C}$} \\
\hline First (failed) attempt to recover CORK & 18 Aug & 0530 & 18 Aug & 1830 & & \\
\hline Manufacture modified CORK recovery tool & 18 Aug & 1830 & 20 Aug & 0600 & & \\
\hline Second (failed) attempt to recover CORK & 20 Aug & 0600 & 20 Aug & 1600 & & \\
\hline Pull out of hole & 20 Aug & 1600 & 20 Aug & 2130 & 64.00 & 2.7 \\
\hline
\end{tabular}


Table T1 (continued).

\begin{tabular}{|c|c|c|c|c|c|c|}
\hline \multirow[b]{2}{*}{ Operational task } & \multicolumn{2}{|c|}{ Start } & \multicolumn{2}{|c|}{ End } & \multicolumn{2}{|c|}{ Task time } \\
\hline & $\begin{array}{l}\text { Date } \\
(2010)\end{array}$ & $\begin{array}{l}\text { Local ship } \\
\text { time (h) }\end{array}$ & $\begin{array}{l}\text { Date } \\
(2010)\end{array}$ & $\begin{array}{l}\text { Local ship } \\
\text { time (h) }\end{array}$ & $\mathrm{h}$ & Days \\
\hline \multicolumn{7}{|l|}{ Hole U1362B (SR-2B) Stage 3} \\
\hline Make up 9-7/8 inch drilling assembly; run in hole & 20 Aug & 2130 & 21 Aug & 0730 & & \\
\hline Drill out cement & 21 Aug & 0730 & 21 Aug & 1030 & & \\
\hline Drill 9-7/8 inch hole to $339 \mathrm{mbsf}$ & 21 Aug & 1030 & 22 Aug & 2200 & & \\
\hline Make up tracer injection BHA with instrument package; run in hole & 22 Aug & 2200 & 23 Aug & 0900 & & \\
\hline First attempt at $24 \mathrm{~h}$ flow test and tracer injection experiment & 23 Aug & 0900 & 23 Aug & 1700 & & \\
\hline Make up 9-7/8 inch drilling assembly; run in hole & 23 Aug & 1700 & 24 Aug & 1315 & & \\
\hline Deepen $9-7 / 8$ inch hole to $359 \mathrm{mbsf}$ & 24 Aug & 1315 & 25 Aug & 2100 & & \\
\hline Make up tracer injection BHA with instrument package; run in hole & 25 Aug & 2100 & 26 Aug & 0800 & & \\
\hline Conduct $24 \mathrm{~h}$ flow test and tracer injection experiment & 26 Aug & 0800 & 27 Aug & 1000 & & \\
\hline Pull out of hole; remove instrument package & 27 Aug & 1000 & 27 Aug & 1615 & & \\
\hline Make up 9-7/8 inch drilling assembly; run in hole; conduct depth check & 27 Aug & 1615 & 27 Aug & 2400 & & \\
\hline Pull out of hole & 27 Aug & 2400 & 28 Aug & 0530 & & \\
\hline Make up CORK assembly with 4-1/2 inch casing, packers, miniscreens, and umbilicals & 28 Aug & 0530 & 29 Aug & 0200 & & \\
\hline Deploy OsmoSamplers, sinker bar, and Spectra rope with thermistors & 29 Aug & 0200 & 29 Aug & 1315 & & \\
\hline Install CORK and pressure up packers & 29 Aug & 1315 & 29 Aug & 1545 & & \\
\hline Deploy ROV platform and release CORK head & 29 Aug & 1545 & 29 Aug & 2230 & & \\
\hline Recover positioning beacon from seafloor & 29 Aug & 2230 & 30 Aug & 0300 & & \\
\hline Pull out of hole; secure rig for transit & 30 Aug & 0300 & 30 Aug & 1300 & 231.50 & 9.6 \\
\hline Transit to Grizzly Bare site & 30 Aug & 1300 & 30 Aug & 1615 & 3.25 & 0.1 \\
\hline \multicolumn{7}{|l|}{ Site U1363 (GRB-1A to GRB-3A) } \\
\hline Make up APC/XCB drilling assembly; run in hole & 30 Aug & 1615 & 30 Aug & 2130 & & \\
\hline Hole U1363A: drill without coring to $58 \mathrm{mbsf}$ & 30 Aug & 2130 & 31 Aug & 0330 & 11.25 & 0.5 \\
\hline Hole U1363B: APC/XCB core to $61 \mathrm{mbsf} ; 4$ APCT-3 and 1 SET deployments & 31 Aug & 0330 & 31 Aug & 2145 & 18.25 & 0.8 \\
\hline Hole U1363C: drill to $150 \mathrm{mbsf}$ XCB core to $203 \mathrm{mbsf} ; 3$ SET deployments & 31 Aug & 2145 & 2 Sep & 0100 & 27.25 & 1.1 \\
\hline Hole U1363D: drill to $198 \mathrm{mbsf}$; XCB core to $231.8 \mathrm{mbsf}$ & 2 Sep & 0100 & 3 Sep & 0700 & 30.00 & 1.3 \\
\hline Hole U1363E: drill without coring to $37 \mathrm{mbsf}$ & 3 Sep & 0700 & 3 Sep & 1130 & 4.50 & 0.2 \\
\hline Hole U1363F: APC core to $35 \mathrm{mbsf} ; 2$ APCT-3 deployments & $3 \mathrm{Sep}$ & 1130 & 3 Sep & 1730 & 6.00 & 0.3 \\
\hline Hole U1363G: APC core to 24.9 mbsf; 1 APCT-3 deployment & 3 Sep & 1730 & 4 Sep & 1015 & 16.75 & 0.7 \\
\hline \multirow[t]{2}{*}{ Transit to Victoria, British Columbia (Canada) } & 4 Sep & 1015 & 5 Sep & 0845 & 22.50 & 0.9 \\
\hline & & & & Totals: & 1388.50 & 58.10 \\
\hline
\end{tabular}

Notes: ${ }^{*}=$ for both $211 \frac{1}{2}$ inch holes, an $181 \frac{1}{2}$ hole was cut $6.3 \mathrm{~m}$ deeper with a tricone bit. Local ship time $=\mathrm{UTC}-7 \mathrm{~h}$. BHA $=$ bottom-hole assembly. $\mathrm{ROV}=$ remotely operated vehicle, $\mathrm{CORK}=$ subseafloor borehole observatory. $\mathrm{RCB}=$ rotary core barrel, $\mathrm{APC}=$ advanced piston corer, $\mathrm{XCB}$ $=$ extended core barrel. APCT-3 = third-generation advanced piston corer temperature tool, SET = sediment temperature tool. Site U1362 total time was 47.7 days.

Table T2. Hole locations during Expedition 327. (See table note.)

\begin{tabular}{ccccr}
\hline Hole & Latitude & Longitude & Seismic line & \multicolumn{1}{c}{ CDP } \\
\hline U1362A & $47^{\circ} 45.6628^{\prime} \mathrm{N}$ & $127^{\circ} 45.6720^{\prime} \mathrm{W}$ & GeoB00-482 & 439 \\
U1362B & $47^{\circ} 45.4997^{\prime} \mathrm{N}$ & $127^{\circ} 45.7312^{\prime} \mathrm{W}$ & GeoB00-476 & 316 \\
U1363A & $47^{\circ} 17.3555^{\prime} \mathrm{N}$ & $128^{\circ} 2.1107^{\prime} \mathrm{W}$ & GeoB00-170 & 2836 \\
U1363B & $47^{\circ} 17.3518^{\prime} \mathrm{N}$ & $128^{\circ} 2.1060^{\prime} \mathrm{W}$ & GeoB00-170 & 2836 \\
U1363C & $47^{\circ} 17.5759^{\prime} \mathrm{N}$ & $128^{\circ} 1.7641^{\prime} \mathrm{W}$ & GeoB00-170 & 2776 \\
U1363D & $47^{\circ} 17.5724^{\prime} \mathrm{N}$ & $128^{\circ} 1.7599^{\prime} \mathrm{W}$ & GeoB00-170 & 2776 \\
U1363E & $47^{\circ} 17.3310^{\prime} \mathrm{N}$ & $128^{\circ} 2.1447^{\prime} \mathrm{W}$ & GeoB00-170 & 2841 \\
U1363F & $47^{\circ} 17.3261^{\prime} \mathrm{N}$ & $128^{\circ} 2.1374^{\prime} \mathrm{W}$ & GeoB00-170 & 2841 \\
U1363C & $47^{\circ} 17.3118^{\prime} \mathrm{N}$ & $128^{\circ} 2.1698^{\prime} \mathrm{W}$ & GeoB00-170 & 2846 \\
U1301B & $47^{\circ} 45.228^{\prime} \mathrm{N}$ & $127^{\circ} 45.827^{\prime} \mathrm{W}$ & GeoB00-466 & 556 \\
1027C & $47^{\circ} 45.387^{\prime} \mathrm{N}$ & $127^{\circ} 43.867^{\prime} \mathrm{W}$ & GeoB00-203 & 741 \\
\hline
\end{tabular}

Note: CDP = common depth point. 
Table T3. Expedition 327 hole summary. (See table note.)

\begin{tabular}{|c|c|c|c|c|c|c|c|c|c|c|c|}
\hline Hole & Latitude & Longitude & $\begin{array}{l}\text { Water } \\
\text { depth } \\
\text { (mbsl) }\end{array}$ & $\begin{array}{l}\text { Cores } \\
(N)\end{array}$ & $\begin{array}{l}\text { Cored } \\
\text { interval } \\
(\mathrm{m})\end{array}$ & $\begin{array}{l}\text { Core } \\
\text { recovered } \\
\text { (m) }\end{array}$ & $\begin{array}{l}\text { Recovery } \\
\text { (\%) }\end{array}$ & $\begin{array}{c}\text { Drilled } \\
\text { interval } \\
(\mathrm{m})\end{array}$ & $\begin{array}{l}\text { Total } \\
\text { penetration } \\
(\mathrm{m})\end{array}$ & $\begin{array}{l}\text { Time } \\
\text { on hole } \\
\text { (h) }\end{array}$ & $\begin{array}{c}\text { Time } \\
\text { on hole } \\
\text { (days) }\end{array}$ \\
\hline U1362A & $47^{\circ} 45.6628^{\prime} \mathrm{N}$ & $127^{\circ} 45.6720^{\prime} \mathrm{W}$ & 2661 & 20 & 150.0 & 44.4 & 30 & 378.0 & 528.0 & 719 & 30.0 \\
\hline U1362B & $47^{\circ} 45.4997^{\prime} \mathrm{N}$ & $127^{\circ} 45.7312^{\prime} \mathrm{W}$ & 2661 & NA & NA & $\mathrm{NA}$ & NA & 359.0 & 359.0 & 427 & 17.8 \\
\hline \multicolumn{4}{|c|}{ Site U1362 totals: } & 20 & 150.0 & 44.4 & 30 & 737.0 & 887.0 & 1146 & 47.8 \\
\hline U1363A & $47^{\circ} 17.3555^{\prime} \mathrm{N}$ & $128^{\circ} 2.1107^{\prime} \mathrm{W}$ & 2678 & NA & NA & NA & NA & 58.0 & 58.0 & 11.25 & 0.5 \\
\hline U1363B & $47^{\circ} 17.3518^{\prime} \mathrm{N}$ & $128^{\circ} 2.1060^{\prime} \mathrm{W}$ & 2679 & 10 & 61.0 & 49.7 & 82 & 0 & 61.0 & 18.25 & 0.8 \\
\hline U1363C & $47^{\circ} 17.5759^{\prime} \mathrm{N}$ & $128^{\circ} 1.7641^{\prime} \mathrm{W}$ & 2678 & 4 & 32.4 & 7.0 & 22 & 170.0 & 202.4 & 27.25 & 1.1 \\
\hline U1363D & $47^{\circ} 17.5724^{\prime} \mathrm{N}$ & $128^{\circ} 1.7599^{\prime} \mathrm{W}$ & 2678 & 4 & 33.8 & 15.0 & 44 & 198.0 & 231.8 & 30.00 & 1.3 \\
\hline U1363E & $47^{\circ} 17.3310^{\prime} \mathrm{N}$ & $128^{\circ} 2.1447^{\prime} \mathrm{W}$ & 2678 & NA & NA & NA & NA & 37.0 & 37.0 & 4.50 & 0.2 \\
\hline U1363F & $47^{\circ} 17.3261^{\prime} \mathrm{N}$ & $128^{\circ} 2.1374^{\prime} \mathrm{W}$ & 2678 & 4 & 35.0 & 31.2 & 89 & 0 & 35.0 & 6.00 & 0.3 \\
\hline \multirow[t]{2}{*}{ U1363G } & $47^{\circ} 17.3118^{\prime} \mathrm{N}$ & $128^{\circ} 2.1698^{\prime} \mathrm{W}$ & 2677 & 3 & 24.9 & 22.9 & 92 & 0 & 24.9 & 16.75 & 0.7 \\
\hline & & \multicolumn{2}{|c|}{ Site U1363 totals: } & 25 & 187.1 & 125.8 & 67 & 463 & 650.1 & 114 & 4.8 \\
\hline U1301B & $47^{\circ} 45.228^{\prime} \mathrm{N}$ & $127^{\circ} 45.827^{\prime} \mathrm{W}$ & 2671 & NA & NA & NA & NA & NA & NA & 18.75 & 0.8 \\
\hline \multirow[t]{2}{*}{$1027 C$} & $47^{\circ} 45.387^{\prime} \mathrm{N}$ & $127^{\circ} 43.867^{\prime} \mathrm{W}$ & 2667 & NA & NA & NA & NA & NA & NA & 64.0 & 2.7 \\
\hline & \multicolumn{3}{|c|}{ Expedition 327 totals: } & 45 & 337.1 & 170.2 & 50 & 1200.0 & 1537.1 & 1342.75 & 55.9 \\
\hline
\end{tabular}

Note: $N=$ number, $N A=$ not applicable. 